University of Missouri School of Law Scholarship Repository

Spring 2021

\title{
The Odious Intellectual Company of Authority Restricting Second Amendment Rights to the "Virtuous"
}

Royce de R. Barondes

Follow this and additional works at: https://scholarship.law.missouri.edu/facpubs

Part of the Second Amendment Commons 


\title{
The Odious Intellectual Company of Authority Restricting Second Amendment Rights to the "Virtuous"
}

\author{
by
}

\section{Royce de R. Barondes*}

\begin{abstract}
To the woes of the victims of American over-criminalization, we can add deprivation of the suitable tools for self-defense during national emergency and civil unrest. Federal law disarms "unlawful users" of controlled substances (including medical marijuana), and imposes a permanent firearms ban on substantially all those with prior felony convictions. A notable exception is made for white-collar criminals with felony violations of antitrust and certain business practice statutes.

The constitutionality of these restrictions typically is founded on the view that one is tainted as "non-virtuous" for any serious criminal conviction, which includes any felony conviction. Using extensive sampling, this article shows that reliance on this theory is discredited outside the context of the Second Amendment. Modern reliance on the theory, outside the context of firearms rights, has been very infrequent and has been used to validate odious statutes, in cases no longer good law.

The unsound judicial effort to derive the validation of these firearms bans from Founding-Era firearms restrictions builds on erroneous premises. The Founding-Era restrictions, detailed in this article, were tailored to the circumstances and do not provide a foundation for the broad, essentially permanent bans that federal law provides and that courts typically validate.
\end{abstract}

\footnotetext{
* James S. Rollins Professor of Law, University of Missouri.

Copyright (C) 2020 Royce de R. Barondes. All rights reserved.
} 


\section{Table of Contents}

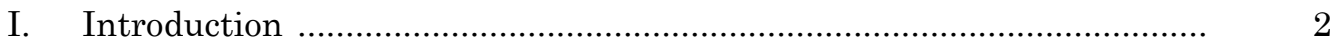

II. The Current Federal Felon Prohibition and Its History .......................

III. Representative Outcomes in Contemporary Second Amendment Challenges to the Felon Ban .................................................................. 15

IV. Founding-Era Conceptualization Limiting Constitutional Rights to the

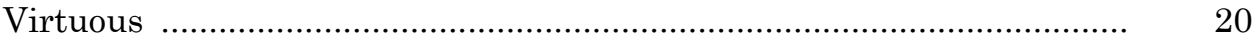

V. The Absence of a Founding-Era Analogue ........................................... 22

A. Modern Cases and the Authority on Which They Rely ................... 23

B. Linking the "Virtuous" to the Need for a Militia ............................. 29

C. Forfeiture for Capital Crime …….................................................... 31

D. Kates' Historical Recitation Is Unpersuasive ............................... 39

E. Actual Founding-Era Limits .......................................................... 41

F. Modern Overcriminalization Having No Founding-Era

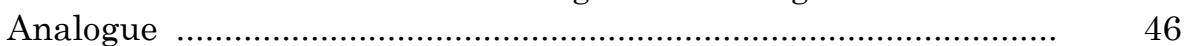

G. Conclusion .................................................................................... 48

VI. Contemporary Cases Referencing the Virtuous Outside the Context of the Second Amendment ........................................................................... 49

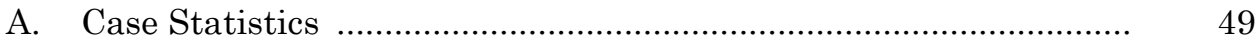

B. Relevant Supreme Court Authority ................................................ 51

C. Apt References to Virtuous Persons in Contemporary Lower-
Court Jurisprudence Citing a Scrutiny Standard ........................... 53



\section{INTRODUCTION}

To the woes of the victims of American over-criminalization, we can add deprivation of the suitable tools for self-defense during national emergency and civil unrest. In 2020, there has been an astonishing increase in persons turning to firearms for self-protection, in which firsttime firearms owners are prominently participating. ${ }^{1}$ Yet federal law provides that for being an "unlawful user" of controlled substances, even medical-marijuana used in compliance with state law, one forfeits the right to possess firearms. ${ }^{2}$ And a generally permanent firearms ban attends any felony conviction, whether related to a propensity for violent

1 E.g., Jim Curcuruto, Millions of First-Time Gun Buyers During COVID-19, NSSF (June 1, 2020), https://www.nssf.org/millions-of-first-time-gun-buyers-during-covid-19/ (noting "year-over-year increases [in retail firearm sales] of 80 percent in March and 69 percent in April 2020," "estimating that 40 percent of [retail] sales were to [first-time gun buyers]," and stating, "The early part of 2020 has been unlike any other year for firearm purchases....").

218 U.S.C. $§ 922($ g)(3) (Westlaw through Pub. L. No. 116-91) (also including persons addicted to controlled substances); Arthur Herbert, Assistant Director, Enforcement Programs and Services, Bureau of Alcohol, Tobacco, Firearms and Explosives, Open Letter to all Federal Firearms Licensees (Sept. 21, 2011), www.atf.gov/firearms/docs/openletter/all-ffls-sept2011-open-letter-marijuana-medicinal-purposes). 
misconduct or not, except—as may epitomize some of the infuriating aspect of over-criminalization - as to posh criminals whose felonies involve certain "business practices." Felony convictions for crimes involving certain business practices do not result in federal forfeiture of one's federal firearms rights. ${ }^{3}$

These prohibitions have profound impacts in some communities. A recent article estimates, "people with felony convictions account for $8 \%$ of all adults and 33\% of the African American adult male population." 4 substantial portion of these persons will have been disarmed for crimes that do not evidence a higher propensity for violent misconduct. ${ }^{5}$ Others will be disarmed by long-stale convictions that are no longer probative of a propensity to violence.

The constitutionality of these firearms prohibitions has been founded on a view that supports disarmament of persons who do not have a heightened propensity to be violent. Courts have relied on the view that one who has committed a requisite predicate act-current unlawful use of controlled substances or conviction for any felony-is not "virtuous," and the non-virtuous for that alone can be deprived of this express right. ${ }^{6}$

Sherry describes the Founding Era conceptualization of the "virtuous" in the following way: "Responsibility, independence and community spirit are some of the modern concepts that come closest to capturing the meaning of civic virtue." It has also been described as involving sublimation of one's personal interests to those of the common good or public welfare. ${ }^{8}$ The rationalization for linking firearms rights to being "virtuous," in brief, is that the Founders perceived a need for a virtuous citizenry, whose exercise of certain civil rights was considered crucial to

\footnotetext{
3 See infra notes 43-53 and accompanying text.

4 Sarah K. S. Shannon et al., The Growth, Scope, and Spatial Distribution of People with Felony Records in the United States, 1948-2010, 54 Demography 1795, 1795 (2017).

5 A survey of 2004 state convictions finds, for example, that the most serious conviction offense for 24 percent of state felony convictions was fraud or mere drug possession. See, e.g., Matthew R. Durose, Bureau of Justice Statistics, State Court Sentencing of Convicted Felons, 2004-Statistical Tables tbl.4.2 (July 1, 2007), https://www.bjs.gov/index.cfm?ty=pbdetail\&iid=1533.

6 E.g., United States v. Yancey, 621 F.3d 681, 685 (7th Cir. 2010) (referencing an historical justification for validating the disarmament of persons with felony convictions as non-virtuous and stating, "And that reasoning applies with equal force to Congress's extension of the firearms ban to another category of habitual criminals with $\S 922(\mathrm{~g})(3) . ") ;$ United States v. Conrad, 923 F. Supp. 2d 843, 850 (W.D. Va. 2013) (stating that authority from the Fourth Circuit holds the Second Amendment "is enjoyed only by "law-abiding, responsible citizens;", that "the government could disarm "unvirtuous citizens;"' and that "a user of controlled and illegal substances[] could not claim the status of being a law-abiding citizen." (quoting United States v. Carter, 669 F.3d 411, 416 (4th Cir. 2012))).

7 Suzanna Sherry, "Without Virtue There Can Be No Liberty," 78 Minn. L. Rev. 61, 69 (1993).

8 See infra note 103 and accompanying text.
} 
effective governance. This perspective is extended by courts to support the view that the non-virtuous can be deprived of firearms rights.

This article catalogues the contemporary status of not extending certain constitutional rights to the "non-virtuous," using sampling to collect a database of illustrative opinions. It formalizes Adam Winkler's casual observations on the subject, provided in the aftermath of the Court's initial recognition of the Second Amendment's protecting an individual right. ${ }^{9}$

The sample reveals that modern reliance on this theory is almost exclusively confined to litigation involving Second Amendment rights. ${ }^{10}$ The contemporary authority addressing the theory in contexts not involving the Second Amendment, in fact, typically rejects the principle. And the primary theme of the infrequent contemporary cases to the contrary, not involving the Second Amendment, is the support of odious governmental restriction on intimate activity that are not good law. If judges validating permanent firearms bans for the "non-virtuous" wish to rely on constitutional constructs modernly discredited and used to validate criminalization of private, non-commercial same-sex and heterosexual intimate activity, their opinions ought to be known by the notorious intellectual company they keep.

In particular, this article reports the results of a review of each reported case since 1969 including the word "virtuous" and referencing one of three contemporary standards of Equal Protection review but not referencing the term "Second Amendment."11 The results indicate that cases depriving persons of firearms rights on the basis they are "non"

9 Adam Winkler, Heller's Catch-22, 56 UCLA L. REV. 1551, 1563 n.67 (2009) (citing, inter alia, Don B. Kates, Jr., The Second Amendment: A Dialogue, 49 LAW \& ConTEMP. Probs., Winter 1986, at 143, 146; and Glenn Harlan Reynolds, A Critical Guide to the Second Amendment, 62 TEnN. L. REV. 461, 480 (1995)).

Adam Winkler noted, "Scholars have offered two historical bases for excluding felons from the Second Amendment": (i) that the amendment's scope, limited to "the people," excludes felons; and (ii) that the Founding-Era understanding was that only "virtuous" citizens benefitted. Id. As we shall see, see infra notes 120-122 and accompanying text, modern jurisprudence typically founds the constitutionality of broad firearms bans arising from prior criminal convictions on the second basis. Relying on exclusion of felons from the set of "the people" was implicitly rejected in District of Columbia v. Heller, 554 U.S. 570, 580 (2008) (quoting United States v. Verdugo-Urquidez, 494 U.S. 259, 265 (1990), where the Court suggests the term "the people" has a common meaning in various parts of the Bill of Rights).

Winkler rejected both of those approaches, and tethered the validity of felon disarmament to felons simply being too dangerous. Winkler, supra, at 1563 n.67. Winkler articulates the principle for rejecting the second-listed principle in this way: "In modern constitutional law, rights are not selectively doled out by legislatures to those whom elected officials deem to be sufficiently virtuous or worthy." Id.

10 See infra Part V.

11 That is, the following Westlaw search of opinions was performed: adv: virtuous \& ("rational basis" or "intermediate scrutiny" or "strict scrutiny"). 
virtuous" are irreconcilable with the principle, articulated in McDonald $v$. City of Chicago, ${ }^{12}$ that the constitutional rights protected by the Second Amendment are not "second-class." 13

Additionally, this article details the mechanism in the Founding Era that would have restrained dangerous conduct of criminals, post-sentence. It shows those arrangements are not analogous the contemporary federal firearms ban, which effects a wholesale, ${ }^{14}$ generally permanent ban on a broad class of persons - a ban that is untethered to any propensity for future violence. Rather, the Founding-Era analogues provided a tailored approach, with an impact that varied based on the circumstances. ${ }^{15}$ And, as is often overlooked, the tailored Founding-Era analogues in fact restricted firearms possession that would not otherwise be a breach of the peace. ${ }^{16}$ In sum, judicial efforts to validate permanent felon prohibitions on firearms possession, on the basis that this view is compelled by the Founding-Era understanding of firearms rights, simply lack an understanding of the historical context.

The remainder of this article proceeds as follows. Part II sketches the current contours of the federal prohibition on firearms possession, and its development. It sketches the oft-overlooked exception in the felon prohibition, referenced above, ${ }^{17}$ for some white-collar crimes. ${ }^{18}$ It also reveals that the current prohibition is not as longstanding as a casual

12561 U.S. 742 (2010).

13 McDonald v. City of Chicago, 561 U.S. 742, 780 (2010) (plurality opinion) ("Municipal respondents, in effect, ask us to treat the right recognized in Heller as a second-class right, subject to an entirely different body of rules than the other Bill of Rights guarantees that we have held to be incorporated into the Due Process Clause."). See also Silvester v. Becerra, 138 S. Ct. 945, 952 (2018) (mem.) (Thomas, J., dissenting from denial of certiorari) ("Nearly eight years ago, this Court declared that the Second Amendment is not a 'second-class right, subject to an entirely different body of rules than the other Bill of Rights guarantees."' (quoting McDonald, 561 U.S. at 780 (plurality opinion)); id. ("The right to keep and bear arms is apparently this Court's constitutional orphan."); Voisine v. United States, 136 S. Ct. 2272, 2292 (2016) (Thomas, J., dissenting) ("[T]he Court continues to 'relegat[e] the Second Amendment to a second-class right."' (second alteration in original) (quoting Friedman v. Highland Park, 136 S. Ct. 447, 450 (mem.) (Thomas, J., dissenting from denial of certiorari))).

By way of perspective, one can note that United States v. Windsor, 570 U.S. 744 (2013), relies on an assertion that the non-enumerated right to join in a homosexual marriage inherently cannot involve a "second-class" or "second-tier" marriage. Id. at 771.

14 As noted below, the federal prohibition has an exception for prior felony convictions involving some "business practices," although some state prohibitions arise from any felony conviction. See infra notes 30,60 and accompanying text. The existence of this federal exclusion is not integral to the representative constitutional analysis under which the federal felon firearms ban is immune from even as-applied challenges. See infra notes 7381, 120-122.

15 See infra Part V.E.

16 See infra note 225 and accompanying text.

17 See supra text accompanying note 3.

18 See infra note 43 and accompanying text. 
reading of the literature might suggest. ${ }^{19}$ This latter observation is relevant, because when the Supreme Court held that the firearms rights secured by the Second Amendment are individual rights (as opposed to some form of collective rights), ${ }^{20}$ it volunteered dicta stating, in relevant part, "[N]othing in our opinion should be taken to cast doubt on longstanding prohibitions on the possession of firearms by felons . . .."21 Although a footnote indicates specified longstanding prohibitions are merely presumptively lawful, ${ }^{22}$ the extent to which restrictions are longstanding is relevant, insofar as courts seek to treat this Supreme Court dicta as announcing an operative standard.

Our development below of the constitutionality of predicate acts creating federal firearms bans focuses on the ban for persons with prior felony convictions. Similar principles have been used to justify the ban applicable to unlawful users of controlled substances. ${ }^{23}$

Part III briefly sketches the approaches courts have taken in challenges to the ban arising from conviction of a crime punishable by imprisonment of more than one year. As noted there, federal circuits hold the extant federal felon firearms possession is facially constitutional, with many (but not all) holding that as-applied challenges are also barred. As noted in Part III, cases broadly validating the felon firearm prohibition rely on the notion that the non-virtuous were excluded from benefitting from constitutionally secured firearms rights.

Part IV briefly sketches the Founding-Era conceptualization of virtuous citizens. That involved "community spirit," and sublimation of personal interests to the common good. Part V demonstrates that the Founding-Era analogues that restricted the activity of dangerous persons are qualitatively different from the current, broad felon firearms bans that some contemporary courts hold are beyond further judicial scrutiny. It shows the thread of judicial authority that broadly validates felon firearms possession, exempting them from as-applied challenges, relies on a disingenuously curated selection of Founding-Era authority.

A focus on the original understanding, to the exclusion of another approach to constitutional interpretation, is taken, because that is the

19 See infra notes 38-54 and accompanying text.

20 District of Columbia v. Heller, 554 U.S. 570, 592 (2008). The holding was made applicable to the states in McDonald v. City of Chicago, 561 U.S. 742, 750 (2010) (plurality opinion).

21 Id. at 626

22 Id. at 627 n.26 ("We identify these presumptively lawful regulatory measures only as examples; our list does not purport to be exhaustive."). See generally C. Kevin Marshall, Why Can't Martha Stewart Have A Gun?, 32 Harv. J.L. \& Pub. PoL'y 695, 696-97 (2009) (critically examining the authority for the felon disenfranchisement dicta).

23 See supra note 6 and accompanying text. The choice in the manner of exposition is dictated by the fact that the primary cases involve felon bans. 
approach the relevant courts take. One supposes that, in light of the ordinary contemporary rejection of the principle that the non-virtuous can be denied express rights, this judicial choice frames the analysis so as to bias it in favor of validating the firearms restrictions.

To read into the Second Amendment an implicit exception for those who had previously committed any serious crime would require that there was a salient understanding, in the Founding Era, ${ }^{24}$ that those persons had permanently forfeited their firearms rights. Because Part V shows there was no such salient Founding-Era understanding, Part VI then examines the principle, occasionally referenced in other contexts, that the non-virtuous may be deprived of constitutional rights.

That Part examines whether the principle is sufficiently recognized that it may on its own justify the general validation of broad felon firearms bans. As noted there, very few cases rely on this theory for depriving a class of persons of constitutional rights. And those that do are no longer good law, validating restrictions on private, non-commercial sexual activity. The statutory restrictions those cases validate are odious. The opinions broadly validating felon firearms bans, and the judges who write those opinions, ought to be known by the odious intellectual company that they keep.

\section{The CURRENT Federal FELON ProhiBition AND ITs History}

In relevant part, federal law currently criminalizes firearms possession by a person who has been convicted ${ }^{25}$ of (i) "a crime punishable

24 There is a threshold issue of whether the historical limit on state restrictions ought to reference the time the Fourteenth Amendment was adopted. E.g., Gould v. Morgan, 907 F.3d 659, 669 (1st Cir. 2018) ("Because the challenge here is directed at a state law, the pertinent point in time would be 1868 (when the Fourteenth Amendment was ratified)."), petition for cert. filed (U.S. Apr. 1, 2019) (18-1272). See generally, e.g., Kurt T. Lash, Beyond Incorporation, 18 J. ConTEMP. Legal Issues 447, 449 (2009) (stating, "This shift in the public understanding of individual liberty suggests that what we are after is not the incorporation of 1787 texts, but the public understanding of 1868 texts . . ."). In light of this article's primary focus on a federal restriction, this article will not probe that understanding.

25 What constitutes a "conviction" is determined by "the law of the jurisdiction in which the proceedings were held.” 18 U.S.C. § 921(a)(20) (Westlaw through Pub. L. No. 116-91). This provision can give rise to peculiar issues. For example, a Missouri suspended imposition of a sentence does not result in a conviction for purposes of depriving a person of his or her federal firearms rights. United States v. Thornton, 766 F.3d 875, 877 \& n.1 (8th Cir. 2014); but cf. United States v. Love, 59 F. App'x 165, 166 (8th Cir. 2003) ("Under Arkansas law, a determination that a person is guilty of a felony is a conviction even though the court suspended imposition of the sentence."). However, in Missouri, a suspended execution of sentence does result in a disqualifying conviction. United States v. Bass, No. 09-CR-00230-DME, 2010 WL 2573990, at*3 (D. Colo. June 23, 2010); see State v. Fikes, 597 S.W.3d 330, 332 n.3 (Mo. Ct. App. 2019), transfer denied (Jan. 23, 2020), transfer denied (Apr. 28, 2020); Berryman v. United States, No. 11-0793-CV-W-DGK, 2012 WL 1438760, at*1 (W.D. Mo. Apr. 25, 2012). 
by imprisonment for a term exceeding one year," 26 colloquially referenced as a ban on felon firearm possession, or (ii) "a misdemeanor crime of domestic violence." 27 Federal law also criminalizes that possession by a person currently subject to a specified type of domestic violence restraining order. ${ }^{28}$

There is a required interstate commerce nexus, but it is extremely broad. It extends, inter alia, to any "possess[ion] in or affecting commerce" and "receiv[ing] any firearm or ammunition which has been shipped or transported in interstate or foreign commerce." 29

However, there are some idiosyncratic limits on what is colloquially referenced as the federal felon firearms ban. First, it excludes "any Federal or State offenses pertaining to antitrust violations, unfair trade practices, restraints of trade, or other similar offenses relating to the regulation of business practices." 30 Second, it excludes "any State offense classified by the laws of the State as a misdemeanor and punishable by a term of imprisonment of two years or less." 31

As a general matter, i.e., subject to some limited exceptions, the current federal felon firearms ban is permanent. ${ }^{32}$ The underlying crime can be either a federal crime or a state crime. The jurisdiction of the predicate crime may endeavor to ameliorate the collateral firearms consequences of the conviction, post-sentence. The actual impact of those restorative actions under federal law is rather complicated, ${ }^{33}$ and we shall not endeavor to detail them here.

2618 U.S.C. $\$ 922(\mathrm{~g})(1)$ (Westlaw through Pub. L. No. 116-91).

2718 U.S.C. $\S 922(\mathrm{~g})(9)$. There are other prohibitions, e.g., for "alien[s] . . illegally or unlawfully in the United State," for unlawful users of controlled substances, persons "adjudicated as ... mental defective[s]," or "committed to . . mental institution[s]." Id. $\S 922(\mathrm{~g})$.

28 Id. $\S 922(\mathrm{~g})(8)$.

29 Id. $\S 922(\mathrm{~g})$.

$30 \quad$ Id. $\$ 921(\mathrm{a})(20)(\mathrm{A})$.

$31 \quad 18$ U.S.C. $\S 921(\mathrm{a})(20)(\mathrm{B})$.

32 A statutorily-authorized process for federal reinstatement of firearms rights has not been funded in recent years. E.g., Kanter v. Barr, 919 F.3d 437, 439 (7th Cir. 2019).

33 Reinstatement of rights under state law may not reinstate rights under federal law. 18 U.S.C. § 921(a)(20) ("Any conviction which has been expunged, or set aside or for which a person has been pardoned or has had civil rights restored shall not be considered a conviction for purposes of this chapter, unless such pardon, expungement, or restoration of civil rights expressly provides that the person may not ship, transport, possess, or receive firearms."). A qualifying restoration of "civil rights" requires restoration of civil rights generally-restoration of firearms rights alone is insufficient. E.g., United States v. Woodall, 120 F.3d 880, 881 (8th Cir. 1997); United States v. Estrella, 104 F.3d 3, 6 (1st Cir. 1997) (stating, "[E]ach of the three core 'civil rights' must be substantially, but not perfectly, restored," and identifying those three as "rights to vote, to hold public office, and to serve on a jury").

Additionally, firearms rights cannot be subject to ongoing limitation. Where state law only partially restores a person's firearms rights following a state conviction initially 
Both the historical development of the federal ban on felon firearms possession and its current scope are often misleadingly described. For example, Joseph Blocher and Darrell Miller write: "The federal ban on possession by felons, for example, did not exist until 1938 and did not extend to all felons until 1968." ${ }^{4}$ Lawrence Rosenthal has written, "The Firearms Act of 1938 required a license to ship firearms in interstate commerce and prohibited transfers to specified classes of individuals including certain convicted felons, fugitives from justice, and persons under indictment." ${ }^{5}$ These statements are misleading in a number of ways.

Dicta in District of Columbia v. Heller, ${ }^{36}$ discussed below, ${ }^{37}$ introduced into the Second Amendment jurisprudence some suggestion that a restriction being longstanding evidences its validity. In that context, what might otherwise be innocuous simplifications, misstating the longevity of firearms restrictions, become substantially misleading. It is therefore important to detail the extent to which only well after 1968 did the portfolio of federal firearms restrictions transition to current restrictive regime.

First, the relevant federal firearms prohibition before 1968 did not provide a complete ban for covered persons with prior felony convictions. Rather, by its terms it was limited to "any firearm . . . which has been shipped or transported in interstate or foreign commerce. ${ }^{38}$ Moreover, it was subject to a narrow interpretation, recited in Tot $v$. United States:39

resulting in a federal firearms prohibition-so there remains a state restriction on the possession of some firearms - the state restoration of rights will not reinstate federal firearms rights. Caron v. United States, 524 U.S. 308, 310 (1998). An ongoing state limit that merely prohibits obtaining a concealed weapons permit has been held sufficient to prevent firearms rights reinstatement under federal law. Van Der Hule v. Holder, 759 F.3d 1043, 1044-45 (9th Cir. 2014). Curiously, if a state conviction does not result in loss of civil rights, the rights are not treated as restored for purposes of 18 U.S.C. $§ 921$. Logan v. United States, 552 U.S. 23, 37 (2007).

34 Joseph Blocher \& Darrell A.H. Miller, What IS Gun Control? Direct Burdens, Incidental Burdens, and the Boundaries of the Second Amendment, 83 U. CHI. L. REV. 295, 327-28 (2016).

35 Lawrence Rosenthal, The Limits of Second Amendment Originalism and the Constitutional Case for Gun Control, 92 WASH. U.L. REv. 1187, 1211-12 (2015). Rosenthal relies in part on an opinion written by Judge Easterbrook. Id. at 1223-24. Easterbrook wrote in part, as to that 1938 act: "The first federal statute disqualifying felons from possessing firearms was not enacted until 1938; it also disqualified misdemeanants who had been convicted of violent offenses. (Technically the crime was 'receipt' of a gun that had crossed state lines; the statute treated possession as evidence of receipt.)" United States v. Skoien, 614 F.3d 638, 640 (7th Cir. 2010) (en banc) (citation omitted).

36554 U.S. 570 (2008).

37 See infra note 114 and accompanying text.

38 Federal Firearms Act, Pub. L. No. 75-785, § 2(f), 52 Stat. 1250, 1251 (1938) (repealed 1968).

39319 U.S. 463 (1943). 
Both courts below held that the offense created by the Act is confined to the receipt of firearms or ammunition as a part of interstate transportation and does not extend to the receipt, in an intrastate transaction, of such articles which, at some prior time, have been transported interstate. The Government agrees that this construction is correct. ${ }^{40}$

So, before 1968, federal law did not inherently criminalize a felon's firearm possession in his or her state of residence.

Second, the current federal ban on possession does not extend to "all" persons with prior felony convictions. In fact, the 1968 federal felon firearm possession ban had multiple components that operated to restrict its scope, which remains in diminished form. The federal prohibition as in effect in 1968 had provisions that, if given full effect, would have made the ban's scope similar to Founding-Era restrictions, which are discussed below. ${ }^{41}$

Per Se Exclusion of Certain Crimes Regulating Business Practices. As noted above, ${ }^{42}$ the crimes that currently gives rise to a federal firearms ban exclude "any Federal or State offenses pertaining to antitrust violations, unfair trade practices, restraints of trade, or other similar offenses relating to the regulation of business practices." 43 The list of disqualifying predicate crimes had been expanded by a 1961 statutory amendment from the more limited set of persons who had committed "crime[s] of violence" 44 (although, as noted above, ${ }^{45}$ the pre-1968 prohibition had a limited scope and did not operate generally to disarm a covered person).

40 Id. at 466 (emphasis added); see also Barrett v. United States, 423 U.S. 212, 226 (1976) (White, J., concurring) ("Thus after Tot, and as long as Congress left $\S 2$ (f) intact, to establish a violation of $\S 2(\mathrm{f})$ it was necessary to prove that a convicted felon found in possession of a firearm actually participated in an interstate shipment.").

41 See infra Part V.E.

42 See supra note 3, 30 and accompanying text.

$43 \quad 18$ U.S.C. $\S 921(\mathrm{a})(20)(\mathrm{A})$. This is not prominently discussed in Blocher \& Miller, supra note 34. A Westlaw search of that article for the relevant textual components of the exclusion (search: adv: (antitrust or "anti-trust" or "trade practices" or "restraints of trade" or "business practices" or "921(a)(20)!") reveals a sole reference to antitrust, and that is not on-point. Blocher \& Miller, supra note 34, at 344 n.282.

44 An Act to Strengthen the Federal Firearms Act, Pub. L. No. 87-342, 75 Stat. 757 (1961); see also Marshall, supra note 22, at 698-99 (discussing the historical development of the federal statutory prohibitions). Continuing our trend of courts overstating the scope of historical firearms restrictions, United States v. Yancey, 621 F.3d 681 (7th Cir. 2010), references "the pedigree of the rule against even nonviolent felons possessing weapons (which was codified in federal law in 1938)," id. at 684, although the limited federal restriction on firearms possession arising from prior criminal convictions, which did not prohibit acquisitions in wholly intrastate transactions, see supra note 38 and accompanying text, was linked to "crime[s] of violence."

45 See supra notes 38-40 and accompanying text. 
Additional Exclusions from Disqualifying Crimes. As developed below, ${ }^{46}$ the Founding-Era procedures for restricting firearms possession by violent persons were tailored, accommodating assessments that limited the restrictions to those who had a propensity for violence, and that had durations that could be tailored to the circumstances. ${ }^{47}$ The first federal act that operated broadly, generally to prevent firearms possession by persons with prior serious convictions, the Gun Control Act of $1968,{ }^{48}$ had multiple mechanisms that can be viewed as seeking to replicate, albeit imperfectly through different means, the type of tailoring that broad firearms prohibitions had in the Founding Era. But the mechanisms used in the Gun Control Act were not implemented efficaciously, and were curtailed or eliminated.

The Gun Control Act of 1968 delegated authority to the Secretary of the Treasury to identify other offenses, similar to antitrust and unfair trade violations, that also would not be disqualifying. ${ }^{49}$ Thoughtful exercise of this administrative authority could have operated to exclude prohibitions being applied to many persons whose convictions did not evidence higher propensities to commit violence, by a broad regulatory interpretation of the statutory language. Thus, that could have been a part of allowing the new, broad federal restrictions to have some significant level of qualitative similarity to the Founding-Era restrictions.

But the Executive Branch, though administrations of both political parties, had no appetite to protect the firearms rights of the nondangerous persons with prior convictions. The authority, apparently, was wholly neglected. ${ }^{50}$

The federal law transitioned in 1986, from a regime in which Congress contemplated that the Executive Branch would protect the firearms rights of certain non-violent offenders, to one that reallocated the neglected authority to the courts. Although this statutory change was part of an act styled the "Firearms Owners' Protection Act,"51 it failed in affording material protection. The courts have been only slightly better in giving effect to that limitation on the federal ban, ${ }^{52}$ which is most succinctly

\footnotetext{
46 See infra Part V.E.

47 See infra Part V.E.

48 Gun Control Act of 1968, Pub. L. No. 90-618, 82 Stat. 1213 (1968) (codified as amended in scattered sections of 18 and 26 U.S.C.).

49 Gun Control Act of 1968, § 102, 82 Stat. at 1216; see also supra note 30.

50 United States v. Stanko, 491 F.3d 408, 414 n.4 (8th Cir. 2007) ("Our research has not revealed any offense so designated by the Secretary under this prior version, nor any indication of Congress's rationale for deleting that language.").

51 Firearms Owners' Protection Act, Pub. L. No. 99-308, 100 Stat. 449 (1986) (codified as amended at 18 U.S.C. $\S \S 921-926$ A, 929; and 26 U.S.C. $§ 5845$ (Westlaw through Pub. L. No. 116-91)).

52 This provision has been given a relatively narrow construction by the courts. United States v. Stanko, 491 F.3d 408, 415-16 (8th Cir. 2007), states, "[I]mplicit in the term
} 
evidenced by cavalier omission of the exception from some statements summarizing the federal firearms prohibitions. That this strand of caselaw started decades before District of Columbia $v$. Heller, ${ }^{53}$ and has analysis inconsistent with Heller, ${ }^{54}$ may account in part for the inefficacy of the statutory provision.

Reinstatement Procedures. The final component of the limits on broad firearms dispossession otherwise created by the Gun Control Act of 1968 for prior serious crimes, in addition to expungement or pardon, ${ }^{55}$ consists of express procedures allowing reinstatement of firearms rights. ${ }^{56}$ However, "[s]ince 1992, Congress has prohibited ATF from expending appropriated funds to investigate or act upon applications for relief from federal firearms disabilities." 57

It is not being suggested that the procedures originally framed in 1986 to allow reinstatement of firearms rights, together with the exclusions for various crimes referenced above, initially resulted in a scope of federal firearms prohibitions equivalent to the scope of the corresponding provisions in the Founding Era. Reinstatement, when last funded, was not

'unfair trade practices' is the requirement of an adverse economic effect on competition or consumers." The exclusion has been found not to extend to prior convictions concerning, inter alia, (i) a fraudulent check-cashing scheme, United States v. Miller, 678 F.3d 649, 651, 653 (8th Cir. 2012); (ii) "conspiracy to manufacture or distribute equipment for decrypting satellite cable signals" and for "willfully infring[ing] a copyright," United States v. Coleman, 609 F.3d 699, 702, 705-06 (5th Cir. 2010); (iii) fraudulent distribution of adulterated meat products and their misbranding, and related deceptive conduct, Stanko, 491 F.3d at 410, 418-19 (asserting that the purpose of predicate crimes was "to protect public health" and that the crimes "do not involve an economic effect on competition or consumers"); (iv) "bringing a lady's wristwatch worth $\$ 9,000$ into the United States by means of a false customs declaration," United States v. Meldish, 722 F.2d 26, 27 (2d Cir. 1983); and (v) importation of tobacco products without paying requisite state tax, United States v. Horma, No. 3:18CR18, 2018 WL 4214136, at *12 (E.D. Va. Sept. 4, 2018). But see Reyes v. Sessions, 342 F. Supp. 3d 141, 144, 156 (D.D.C. 2018) (holding, inter alia, prior conviction under section 10(b) of the Securities Exchange Act of 1934, 15 U.S.C. $\S 78$ j(b), for securities fraud, arising from false filings with the Securities and Exchange Commission, is within the exception). See generally United States v. Geyler, 932 F.2d 1330, 1336 n.9 (9th Cir. 1991) (indicating federal convictions for "mail fraud or securities fraud" are outside the exception), abrogated on other grounds by Beecham v. United States, 511 U.S. 368 (1994).

53554 U.S. 570 (2008).

54 E.g., Meldish, 722 F.2d at 28 (stating, "Because the receiving and possessing of firearms is not a basic constitutional right, the classification must be upheld if it has any rational support.").

55 See supra note 33 and accompanying text.

56 See Gun Control Act of 1968, Pub. L. No. 90-618, § 102, 82 Stat. 1213, 1225 (1968) (codified in pertinent part, as amended, in 18 U.S.C. § 925(c) (Westlaw through Pub. L. No. 116-91)).

57 Granting of Relief; Federal Firearms Privileges, 84 Fed. Reg. 1491, 1492 (Feb. 4, 2019). However, since 1993, the prohibition has not applied to corporations' requests. Id. 
widespread. Only 313 persons had firearms rights reinstated in 1991 through the above-described procedure. ${ }^{58}$

Rather, the point is that courts or scholars may be inclined to frame the federal restrictions as banning, since 1968 (or some earlier point in time), firearms possession by all persons with prior felony convictions, so that such restrictions are "longstanding" and, thus, deemed constitutional under dicta in Heller. And that framing is simply incorrect. The broad federal ban for those with prior convictions, first adopted in 1968, had a number of exceptions that allowed judicial and Executive Branch action to mitigate the broad ban, so that the federal ban could have had an impact similar to the results of the tailored process extant in the Founding Era. And notwithstanding a general congressional logjam in respect of firearms rights, Congress in 1986 endeavored to make efficacious one of the previously neglected curbs on those firearms restrictions, albeit again without much effect.

It is a separate question whether, if those curbs had been vigorously implemented in the 1970s, any variation in their structure or impact from the Founding-Era analogue would have been too substantial from the Founding-Era restrictions to be constitutional. But, whatever the proper analysis of those counterfactual possibilities would be, it remains clear that the current, broad restriction dates only from 1993 (although the ban as to violent persons with prior felony convictions would predate that ${ }^{59}$ ), and it is not as a whole "longstanding."

State Prohibitions. There are, of course, state prohibitions on firearms possession arising from prior convictions. The acts giving rise to a prohibition in some states include, inter alia, the commission of any felony $^{60}$ (or even an out-of-state misdemeanor that would be a felony if

58 See Granting of Relief, Federal Firearms Privileges, 56 Fed. Reg. 65,926 (Dec. 19, 1991); Granting of Relief, Federal Firearms Privileges, 56 Fed. Reg. 36,865 (Aug. 1, 1991); Granting of Relief, Federal Firearms Privileges, 56 Fed. Reg. 26,713 (June 10, 1991); Granting of Relief, Federal Firearms Privileges, 56 Fed. Reg. 14971 (Apr. 12, 1991).

59 Reinstatement was denied in the Gun Control Act of 1968 to persons with felonies involving the use of firearms. Gun Control Act of 1968, § 102 (adding 18 U.S.C. § 925(c)). Those crimes, and some other set of violent crimes, would not have involved regulation of business practices, and could not have been excluded by Executive Branch action.

60 E.g., GA. Code ANN. § 16-11-131(b), (d) (Westlaw through Laws 2020, Act 322) (prohibition for one "who has been convicted of a felony by a court of this state or any other state; by a court of the United States including its territories, possessions, and dominions; or by a court of any foreign nation," but providing a restoration procedure where the predicate crime was an antitrust, etc., violation); MASS. GEN. LAws ANN. ch. 140, § 129C (Westlaw through Ch. 44 of the 2020 2d Ann. Sess.) (criminalizing firearms possession by one not possessing a firearm identification card, subject to various exceptions); id. $\S 129 \mathrm{~B}(1)$ (i), (ii) (prohibiting issuance of firearm identification card to person with prior felony conviction, whether under federal, Massachusetts or other state jurisdiction); id. ch. $269, \S 10$ (h) (setting punishment for firearms possession absent compliance with $\S 129 \mathrm{C}$ ); Minn. StAT. ANN. §624.713.1(10)(i) (Westlaw through legislation effective through Apr. 18, 
committed in-state) ${ }^{61}$ _ so a state felon firearm ban may be broader than the federal one. However, a state ban may not be permanent ${ }^{62}$ or may have some complex nuance. ${ }^{63}$

Assessment of the constitutionality of the federal felon prohibition on firearms possession requires one keep in mind certain basic principles underlying heightened levels of constitutional scrutiny. The presence of a mismatch between the objective of a restriction on a constitutional right and the means used raises concerns that the restriction reflects proscribed hostility to the right, as opposed to advancing the putative interest; the mismatch urges against its constitutionality. ${ }^{64}$ The current federal ban,

2020); Nev. Rev. Stat. ANn. § 202.360(1)(b) (Westlaw through 80th Reg. Sess. (2019)) (expressly referencing felonies under the laws of another state or the United States); VA. Code ANN. § 18.2-308.2(A) (Westlaw through 2019 Reg. Sess. and 2020 Reg. Sess, cc. 1, 64, 198, 201, 202, 247, 249, 255, 278, 356, 478, 603, 620, 659, 660, 701, 808, 831, 941, 1093, $1200,1202,1220,1231,1234 \& 1272$ ) (providing prohibition arising from any felony, expressly referencing crimes in other states and under federal law, but providing restoration procedure).

61 Mo. AnN. STAT. § 571.070.1(1) (Westlaw through 2019 1st Reg. Sess. and 1st Extra. Sess. of the 100th Gen. Assembly) (criminalizing firearms possession by one "convicted of a felony under the laws of this state, or of a crime under the laws of any state or of the United States which, if committed within this state, would be a felony"); WIS. STAT. ANN. § 941.29(1m)(b) (Westlaw through 2019 Act 186) (referencing conviction "of a crime elsewhere that would be a felony if committed in this state"); State v. Campbell, 642 N.W.2d 230, 232-33 (Wis. Ct. App. 2001) (noting that although the predicate crime in Ohio involved acts within Wisconsin's corresponding felony, although the Ohio statute omitted an element in the corresponding Wisconsin statutory felony; holding the predicate crime prohibited firearms possession). See generally La. Rev. STAT. ANN. § 14:95.1(A) (Westlaw through the 2019 Reg. Sess.) (prohibiting firearms possession by a person convicted of assorted Louisiana crimes or a person "who has been convicted under the laws of any other state or of the United States or of any foreign government or country of a crime which, if committed in this state, would be one of the above-enumerated crimes").

Other anomalies arise from a conviction in one state creating a prohibition in another state. In Hamilton v. Pallozzi, 848 F.3d 614 (4th Cir. 2017), the complainant previously had "his civil rights restored by the Governor of Virginia and his firearms rights restored by the Virginia courts." Id. at 617. Hamilton validates Maryland's determination that the conviction continued to result in a Maryland prohibition, until such time as the Virginia Governor provided the complainant a "full pardon." Id. at 628. Similar issues are presented in Moran v. Wisconsin Department of Justice, 932 N.W.2d 430, 443-34, 436 (Wisc. Ct. App. 2019) (reaching a similar conclusion as to a Wisconsin prohibition).

62 E.g., Alaska Stat. ANN. § 11.61.200(a)(1), (b)(1)(C) (Westlaw through ch. 31, 2020 2d Reg. Sess.) (providing felon prohibition ends 10 years after "unconditional discharge on the prior offense," excluding homicide convictions); N.M. STAT. ANN. § 30-7-16(A)(1), (D)(3) (Westlaw through laws in effect through May 20, 2020) (providing felon prohibition lasting ten years from later of completion of sentence or probation); OR. Rev. STAT. AnN. $\S 166.270(1)$, (4)(a) (Westlaw through 2020 Reg. Sess.) (excluding most convictions upon 15 years after imprisonment, parole or probation).

63 E.g., Tex. Penal Code Ann. § 46.04(a) (Westlaw through 2019 Reg. Sess.) (permanent ban from felony conviction, except for possession at "the premises at which the person lives" at least five years following release from confinement or, if later, release from supervision or parole).

64 In discussing strict scrutiny, Peter Rubin notes: 
disarming some nonviolent offenders, but not visiting the harsh consequences on select white-collar criminals, reflects that form of dubious mismatch.

\section{REPRESENTATIVE OUTCOMES IN CONTEMPORARY SECOND AMENDMENT CHALLENGES TO THE FELON BAN}

A typical contemporary treatment of as-applied challenges to felon firearms possession involves a two-step process. ${ }^{65}$ In the first step, the court determines whether the individual is within the scope of the protection of the Second Amendment. A misdemeanor conviction may be deemed "serious" for this purpose. ${ }^{66}$

At this stage, a court may frame the issue as the Second Amendment's protection only extending to the virtuous. ${ }^{67}$ So, at this step, a court may

[T]he inquiry into narrow tailoring-into the fit between classification and proffered goal-serves at least three distinct purposes. First, it ensures that the stated purpose was indeed the actual purpose behind the classification. A narrow tailoring inquiry can help to "smoke out" illegitimate purposes by demonstrating that the classification does not, in fact, serve the stated, legitimate purpose."

Peter J. Rubin, Reconnecting Doctrine and Purpose: A Comprehensive Approach to Strict Scrutiny After Adarand and Shaw, 149 U. Pa. L. Rev. 1, 14 (2000) (citing City of Richmond v. J.A. Croson Co., 488 U.S. 469, 493 (1989) (plurality opinion)).

65 See, e.g., Binderup v. Att. Gen. U.S., 836 F.3d 336, 346-47 (3d Cir. 2016) (plurality opinion) (citations omitted) ("At step one of the Marzzarella decision tree, a challenger must prove ... that a presumptively lawful regulation burdens his Second Amendment rights. This requires a challenger to clear two hurdles: he must (1) identify the traditional justifications for excluding from Second Amendment protections the class of which he appears to be a member, and then (2) present facts about himself and his background that distinguish his circumstances from those of persons in the historically barred class." (citing United States v. Marzzarella, 614 F.3d 85 (3d Cir. 2010)). See generally David B. Kopel \& Joseph G.S. Greenlee, The Federal Circuits' Second Amendment Doctrines, 61 ST. LouIs U. L.J. 193, 227-28 (2017) (collecting cases).

66 See infra note 94 and accompanying text.

67 Binderup v. Attorney General United States, 836 F.3d 336, 348-49 (3d Cir. 2016), states:

"[M] ost scholars of the Second Amendment agree that the right to bear arms was tied to the concept of a virtuous citizenry and that, accordingly, the government could disarm 'unvirtuous citizens.' " Several of our sister circuits endorse the "virtuous citizen" justification for excluding felons and felon-equivalents from the Second Amendment's ambit.

People who have committed or are likely to commit "violent offenses"-crimes "in which violence (actual or attempted) is an element of the offense,"- -undoubtedly qualify as "unvirtuous citizens" who lack Second Amendment rights. But Heller recognized "longstanding prohibitions on the possession of firearms by felons," not just violent felons. The category of "unvirtuous citizens" is thus broader than violent criminals; it covers any person who has committed a serious criminal offense, violent or nonviolent. To the extent Barton suggests that people who commit serious crimes retain or regain their Second Amendment rights if they are not likely to commit a violent crime, it is overruled.

Id. at 348-49 (alteration in original) (citations omitted) (first quoting United States v. Yancey, 621 F.3d 681, 684-85 (7th Cir. 2010); then quoting United States v. Skoien, 614 
conclude that a prior serious conviction puts the individual outside the protection of the Second Amendment. ${ }^{68}$

If the claimant is not within the protection of the Second Amendment, any subsequent review will be under a highly deferential approach such as a rational basis test. ${ }^{6}$ This may be the case, even if the claimant thereafter led an exemplary life..$^{70}$

Otherwise, in the second step, the court needs to ascertain the standard of review-because the Supreme Court has not settled on a standard of review. ${ }^{71}$ And, of course, it would need to apply that standard.

Some federal circuits allow as-applied challenges by persons subject to the felon firearms ban in section $922(\mathrm{~g})(1) ;{ }^{72}$ others do not. The Seventh Circuit noted in 2019:

Relying on the "presumptively lawful" language in Heller and McDonald, every federal court of appeals to address the issue has held that $\S 922(\mathrm{~g})(1)$ does not violate the Second Amendment on its face.

However, courts of appeals are split as to whether as-applied Second Amendment challenges to $§ 922(\mathrm{~g})(1)$ are viable. On the one hand, the Fifth, Sixth, Ninth, Tenth, and Eleventh Circuits have suggested that $\S 922(\mathrm{~g})(1)$ is always constitutional as applied to felons as a class, regardless of their individual circumstances or the nature of their offenses.

The First Circuit has not foreclosed as-applied challenges, but it has expressed some skepticism about them....

F.3d 638, 640, 642 (7th Cir. 2010) (en banc); then quoting District of Columbia v. Heller, 554 U.S. 570, 626 (2008)) (citing United States v. Barton, 633 F.3d 168, 174 (3d Cir. 2011), overruled by Binderup, 836 F.3d 336 (3d Cir. 2016)).

68 But see Barton, 633 F.3d at 174 (stating, "Similarly, a court might find that a felon whose crime of conviction is decades-old poses no continuing threat to society. The North Carolina Supreme Court did just that in Britt v. State, 363 N.C. 546, 681 S.E.2d 320 (2009), finding that a felon convicted in 1979 of one count of possession of a controlled substance with intent to distribute had a constitutional right to keep and bear arms, at least as that right is understood under the North Carolina Constitution."), overruled by Binderup, 836 F.3d 336.

69 E.g., Medina v. Whitaker, 913 F.3d 152, 156 (D.C. Cir. 2019), cert. denied sub nom. Medina v. Barr, No. 19-287, 2019 WL 6689673 (U.S. Dec. 9, 2019).

70 E.g., Medina, 913 F.3d 152, 160-61 (D.C. Cir. 2019) ("A prohibition on firearm ownership, like these other disabilities, is a reasonable consequence of a felony conviction that the legislature is entitled to impose without undertaking the painstaking case-by-case assessment of a felon's potential rehabilitation.").

71 District of Columbia v. Heller, 554 U.S. 570, 634 (2008) (noting the dissent "criticizes us for declining to establish a level of scrutiny for evaluating Second Amendment restrictions").

7218 U.S.C. $§ 922(\mathrm{~g})(1)$ (Westlaw through Pub. L. No. 116-91). 
On the other hand, we, along with the Fourth, Eighth, and D.C. Circuits, have left room for as-applied challenges to the statute. ${ }^{73}$

Federal courts within the Third Circuit have at times seemed relatively aggressive in reviewing bans arising from prior convictions. The en banc decision in Binderup v. Attorney General United States ${ }^{74}$ gave rise to a fractured analysis set forth in three opinions: an opinion announcing the judgment of the court, ${ }^{75}$ a concurrence in part and in the judgment, ${ }^{76}$ and a concurrence in part and a dissent in part. ${ }^{77}$ The opinion announcing the judgment concludes an individual can, in an as-applied claim, demonstrate a state misdemeanor triggering the federal possession ban is not sufficiently serious to put him or her outside the protection of the Second Amendment. ${ }^{78}$

Binderup addresses certain convictions treated as misdemeanors under state law but punishable by more than two years. In the opinion announcing the court's judgment, the court finds the individuals demonstrated they had not been convicted of "serious crimes." Hence, they had adequately demonstrated they were not in the class of "persons historically excluded from the right to arms."79

Where courts have allowed as-applied challenges for disqualifications arising from crimes deemed less serious, a not uncommon view would treat a serious offense as permanent stain-one that cannot be cleansed by subsequent honorable conduct. For example, Tripodi v. Sessions ${ }^{80}$ states, "As a result, 'the passage of time or evidence of rehabilitation' will not 'restore the Second Amendment rights of people who committed serious crimes.' Any allegations regarding the age of the conviction or the offender's rehabilitation are thus irrelevant to our analysis." 1

A few cases hold that the statutory disqualifications from firearms possession either (i) are unconstitutional, as applied, or (ii) adequately alleged a constitutional violation. We can provide a few illustrations. Courts have held there were adequate allegations of a Second Amendment violation arising from prohibitions for:

73 Kanter v. Barr, 919 F.3d 437, 442-43 (7th Cir. 2019) (citations omitted).

$74 \quad 836$ F.3d 336 (3d Cir. 2016) (en banc).

75 Binderup, 836 F.3d at 339 (Ambro, J.) (announcing the judgment of the court).

76 Binderup, 836 F.3d at 357 (Hardiman, J.) (concurring in part and concurring in the judgment) (joined by four other judges).

77 Binderup, 836 F.3d at 380 (Fuentes, J.) (concurring in part and dissenting in part) (joined by six other judges).

78 Binderup, 836 F.3d at 349, 351-52 (Ambro, J.) (announcing the judgment of the court).

79 Binderup, 836 F.3d at 353 (Ambro, J.) (announcing the judgment of the court).

80339 F. Supp. 3d 458 (E.D. Pa. 2018).

81 Tripodi, 339 F. Supp. 3d at 463 (E.D. Pa. 2018) (footnote omitted) (quoting Binderup, 836 F.3d at 349 (plurality opinion)). 
(i) a conviction for driving under the influence, having a 2-1/2 year a maximum possible sentence; ${ }^{22}$ and

(ii) possession of a short-barreled shotgun whose barrel had been shortened after having been damaged. ${ }^{83}$

Courts have held it unconstitutional to found a permanent federal firearms prohibition on the following predicate crimes: ${ }^{84}$

(i) a guilty plea, made eighteen years prior, to corrupting a minor, arising from a consensual sexual relationship with a 17-year-old employee (a misdemeanor punishable by up to five years); 85

(ii) a stale (26-year-old) state misdemeanor conviction for unlawfully carrying a handgun without a license (punishable by up to three years), against a person now holding a "Secret" federal government security clearance in connection with his job as a consultant for a government contractor; 86

(iii) a correction officer's predicate state misdemeanor conviction for carrying an unlicensed firearm; 87 and

(iv) a misdemeanor conviction for alteration of documentation allowing car window tint, so as to make it appear to apply it to a different vehicle. ${ }^{88}$

There are, however, recent cases less charitable in treating requests for reinstatement following a stale adverse mental health determination ${ }^{89}$

82 Baginski v. Lynch, 229 F. Supp.3d 48, 49, 57 (D.D.C. 2017) (denying summary judgment for the government).

83 Robinson v. Lynch, No. 2:16-CV-00150-DB-EJF, 2017 WL 1131896, at *2 (D. Utah Mar. 24, 2017) (“The Court finds Mr. Robinson's proposed Amended Complaint pleads particular facts likely making plausible his claim that $\S 922(\mathrm{~g})(1)$, as applied to the 'severable subcategory of persons' to which Mr. Robinson belongs, deprived Mr. Robinson of his constitutional rights."); First Amended Complaint at 3-4, Robinson, No. 2:16-CV00150-DB-EJF, 2017 WL 1131896 (D. Utah Mar. 24, 2017) (identifying predicate crime as involving conviction for possession of a short-barreled shotgun, whose barrel had been shortened after having been damaged).

84 We are here examining the ban arising from prior criminal convictions. We are not detailing challenges to other bans, e.g., arising from a prior determination of mental incapacity. E.g., Keyes v. Lynch, 195 F. Supp. 3d 702, 706-08, 720 (M.D. Pa. 2016) (holding unconstitutional a ban arising from an eight-day involuntary commitment, at the age of 15 precipitated by the divorce of the claimant's parents, of an Army veteran now a correctional officer whose employment involves carrying a firearm). See also Tyler v. Hillsdale Cty. Sheriff's Dep't, 837 F.3d 678, 681, 683, 699 (6th Cir. 2016) (en banc) (lead opinion) (holding there were adequate allegations of a Second Amendment violation arising from a prohibition based on a two- to four-week commitment, thirty years prior, after a divorce).

85 Binderup, 836 F.3d at 340, 356-57 (Ambro, J.) (announcing the judgment of the court).

86 Id. at 340, 356-57.

87 Clark v. Sessions, 336 F. Supp. 3d 535, 538, 542, 545 (W.D. Pa. 2018) (crime punishable by up to five years incarceration).

88 Miller v. Sessions, 356 F. Supp. 3d 472, 476, 485 (E.D. Pa. 2019).

89 E.g., Simpson v. Sessions, Civil Action No. 16-1334, 2017 WL 1910141, at * $1,{ }^{*} 6$ (E.D. Pa. May 10, 2017) (stating in dismissing claims seeking injunctive relief by a person 
or challenging a ban arising from conviction for particular crimes. ${ }^{90}$ Illustrative recent circumstances arose from:

(i) a prior federal felony conviction for misprision of felony; 91

(ii) a twenty-seven-year-old federal felony conviction for "making a false statement to a lending institution," in connection with applying for a $\$ 30,000$ loan; 92

(iii) a federal felony conviction for making a false statement in a matter within the jurisdiction of the Executive Branch, involving a false claim on forms for unemployment insurance and omission of 53 days of actual work, resulting in the wrongful receipt of $\$ 1,628 ; 93$

(iv) a state misdemeanor conviction for driving under the influence (treating the misdemeanor as "serious" and holding the challenge failed at the first step); ${ }^{94}$

(v) a federal felony conviction for fraud arising from sale of foot inserts falsely described as meeting Medicare thickness requirements (based on application of the second step of the analysis, eliding application of the first step); ${ }^{95}$

involuntarily committed for two days, fifteen years prior, "[T]he passage of time is immaterial to the analysis in this matter. There is no exception to $\S 922(\mathrm{~g})(4)$ for the passage of time.").

90 Dave Kopel and Joseph Greenlee state, "No convicted violent felon has succeeded in an as-applied challenge to the federal statute." Kopel \& Greenlee, supra note 65, at 226.

91 United States v. Phillips, 827 F.3d 1171, 1173-75 (9th Cir. 2016).

92 Medina v. Whitaker, 913 F.3d 152, 154, 160 (D.C. Cir. 2019) (stating, "[W]e hold that those convicted of felonies are not among those entitled to possess arms," and "[The claimant] argues that an examination of his 'present, complete character' places him back within the class of 'law-abiding, responsible citizens.' We disagree."), cert. denied sub nom. Medina v. Barr, No. 19-287, 2019 WL 6689673 (U.S. Dec. 9, 2019).

93 Hatfield v. Barr, 925 F.3d 950, 951-53 (7th Cir. 2019); Hatfield v. Sessions, 322 F. Supp. 3d 885, 887 (S.D. Ill. 2018) (identifying the number of days), rev'd sub nom. Hatfield v. Barr, 925 F.3d 950 (7th Cir. 2019).

94 Holloway v. Att. Gen. U.S., 948 F.3d 164, 173, 177-78 (3d Cir. 2020) (stating "that Holloway's DUI conviction constitutes a serious crime, placing him within the class of 'persons historically excluded from Second Amendment protections.' Because Holloway has not met his burden at the first step of the analysis to overcome the presumptive application of $\S 922(\mathrm{~g})(1), \S 922(\mathrm{~g})(1)$ is constitutional as applied to him, and he is not entitled to relief." (plurality opinion) (footnote omitted) (quoting Binderup v. Att. Gen. U.S., 836 F.3d 336, 347 (3d Cir. 2016)); see also Williams v. Barr, 379 F. Supp. 3d 360, 364, 380 (E.D. Pa. 2019) (stating, "The statistical evidence shows that individuals convicted of an alcohol-related offense have a four to five-fold increase of being arrested for a crime of violence or firearmrelated offense, as compared to individuals with no prior criminal history."); State v. Culver, 918 N.W.2d 103, 106, 115 (Wis. Ct. App. 2018) (addressing a felony predicate offense), review denied, 923 N.W.2d 165 (Wis. 2019).

95 Kanter v. Barr, 919 F.3d 437, 438, 440, 447, 451 (7th Cir. 2019) (applying the second step of the analysis without deciding whether the predicate felony resulted in the challenge failing the first step). 
(vi) a ten-year-old guilty plea to a state misdemeanor for theft of two saws worth a total of $\$ 1,900$, which was punishable by up to five years incarceration, holding the challenge failed at the first step; 96

(vii) a seven-year-old federal felony conviction for filing a false tax return, for which the individual had made a $\$ 257,796.39$ restitution payment, holding the challenge failed at the first step; 97 and

(viii) a guilty plea to a state felony for tampering with state records, punishable by up to seven years imprisonment, arising from overbilling the state in operation of a funeral business and failure to forward reimbursements and ultimately resulting in payment of $\$ 7,125$ in restitution. ${ }^{98}$

\section{FOUNDING-ERA CONCEPTUALIZATION LIMITING CONSTITUTIONAL RIGHTS TO THE VIRTUOUS}

This Part briefly summarizes the relationship between the need for a virtuous citizenry and the broad contours of the governance structure envisioned by the founders. Our summary yields the following conclusions: There was an appreciation for a need for a "virtuous" citizenry. But "virtuous" in this context had a different connotation from the contemporary one. It contemplated participation in governance, sublimating personal interests to the needs of the public.

Suzanna Sherry has written, "Eighteenth century Americans believed that their experiment with liberty would stand or fall on the civic virtue of the citizenry." 99 She provides an introductory description of "civic virtue" as "a general picture of citizens who are willing and able to participate in the public life of their community and their nation." 100 Sherry wryly illustrates the divergence between the connotation of a "virtuous" citizen

96 Baumiller v. Sessions, 371 F. Supp. 3d 224, 228, 233 (W.D. Pa. 2019).

97 Folajtar v. Barr, 369 F. Supp. 3d 617, 618-19 \& n.4, 622, 624 (E.D. Pa. 2019).

98 United States v. Irving, 316 F. Supp. 3d 879, 882-883, 888, 893 (E.D. Pa. 2018) (stating, "[A] $\mathrm{s}$ a felon convicted of a serious crime, Hunt Irving fell outside the protection of the Second Amendment . . . ."), appeal filed sub nom. United States v. Hunt-Irving, No. 191636 (3d Cir. Mar. 25, 2019).

99 Suzanna Sherry, “Without Virtue There Can Be No Liberty,” 78 Minn. L. REV. 61, 68 (1993).

100 Sherry, supra note 99, at 68. Sherry elaborates as follows:

When eighteenth century Americans spoke of virtue, they invoked several intertwined ideas, all of which stemmed from the classical tradition of political participation as the highest human good. Responsibility, independence and community spirit are some of the modern concepts that come closest to capturing the meaning of civic virtue. A virtuous citizen had an independent mind and a willingness to use it for the good of the community. Virtue meant taking responsibility for oneself and one's community. Virtue also meant letting reason control passion, letting long-term community interests override selfish individual wants. Citizens in a virtuous republic deliberated rationally about what would best serve the interests of the community.

Id. at 69 . 
in the era of the Revolutionary War and in modern times. She writes, "One of my colleagues snickered when he first heard the title of this speech; he assumed that 'virtue' was used in its predominant modern sense of sexual chastity. In the eighteenth century, however, 'virtue' meant something quite different." 101

Some of Sherry's Founding-Era illustrations include: "Samuel Adams wrote that men 'will be free no longer than while they remain virtuous.' His cousin and political opposite, John Adams, said that 'public Virtue is the only Foundation of Republics." 102 Stephen Feldman has written:

Under republican democracy, citizens and elected officials were supposed to be virtuous; in the political realm, they were to pursue the common good or public welfare rather than their own partial or private interests. When citizens or officials used government institutions to pursue their own interests, then the government was corrupt. ${ }^{103}$

Academic commentary long ago focused on the relationship between this need for a virtuous citizenry and the Second Amendment. ${ }^{104}$ David Williams, for example, notes "Service in the militia trained one to a life of virtue, both self-sacrificing and independent . . . " 105 He further notes, "Colonial records are full of complaints that the militia, reflecting the sentiment of the people, refused to enforce edicts perceived as unjust, or even participated in popular resistance to them. Colonial culture accepted some measure of violent resistance as a normal part of life, although those in authority never ceased to complain of that fact."106

A need for a particular form of militia participation is, of course, a separate matter from whether a class of certain persons-persons deemed not virtuous-would be permanently disarmed. To say that one class of

101 Sherry, supra note 99, at 69.

102 Id. at (footnote omitted) (first quoting Letter from Samuel Adams to John Scollay (Dec. 30, 1780), in 4 The Writings of SAmuel AdAms 236, 238 (Harry Alonzo Cushing ed., 1908); then quoting Letter from John Adams to Mercy Warren (April 16, 1776), in 1 THE Founders' Constitution 670 (Philip Kurland \& Ralph Lerner eds., 1987)).

103 Stephen M. Feldman, The End of the Cold War: Can American Constitutionalism Survive Victory?, 41 OHIо N.U. L. REV. 261, 264 (2015) (footnote omitted); see also, e.g., Richard A. Epstein, Beyond the Rule of Law: Civic Virtue and Constitutional Structure, 56 GEO. WASH. L. REV. 149, 155-56 (1987) (discussing "civic virtue" as "an important concern in political theory both before and during the framing of our constitution"); Alan Hirsch, Direct Democracy and Civic Maturation, 29 HASTIngs Const. L.Q. 185, 191 (2002) ("In Federalist 55, [Madison] reiterated that republican government presupposes 'sufficient virtue among men for self-government.' " (quoting The Federalist No. 55, at 346 (James Madison) (Clinton Rossiter ed., 1961)).

104 E.g., David C. Williams, Civic Republicanism and the Citizen Militia: The Terrifying Second Amendment, 101 YALE. L.J. 551 (1991); see also infra notes 120-124 and accompanying text.

105 Id. at 556

$106 I d$. at 581 (footnote omitted). 
persons is needed to engage in some activity says nothing about the propriety of treating the complementary class of persons in a particular way. In the immediately following Part V, we illuminate that, in fact, the Founding-Era treatment of those one might categorize as "non-virtuous," on account of some prior conviction for serious crimes, were not inherently subject to permanent firearms bans.

\section{The ABSEnce of A Founding-ERA ANALOGUE}

Other works have addressed certain aspects of the collateral consequences, in the Founding Era, of the commission of a felony, as that term was then used. The purpose of this Part is not to attempt to provide a comprehensive treatment of that historical context. Rather, the core of this article is to address the contemporary treatment of the rights of persons classified as not virtuous, and to put in context assertions that the Founding-Era treatment of the non-virtuous mandates that there is an implicit restriction appended to the Second Amendment, by which all who have committed felonies are excluded. Our presentation of perspectives from centuries ago is limited to providing the backdrop necessary to contextualize our core investigation.

Subpart A notes the link identified in some contemporary jurisprudence that ties benefit under the Second Amendment to being virtuous. The seminal is analysis in some late twentieth-century scholarship by Don Kates. Subpart B illuminates the logical fallacy in finding the Founding-Era's perception of a need for a virtuous citizenry to man the militia implies some adverse treatment of "non-virtuous" citizens was mandated. The discredited view does not demonstrate non-virtuous persons were permanently disarmed, and it is inconsistent with Heller's acknowledgement that benefit from the Second Amendment is decoupled from militia service.

Subpart $\mathrm{C}$ reveals that broad validation of felon firearms bans reflects an erroneous understanding of the Founding-Era consequences of forfeiture associated with commission of capital crimes. Subpart D shows the historical record on which the relevant cases rely is a disingenuously curated selection of Founding-Era authority. Subpart E shows the Founding-Era analogues restricting the activity of dangerous persons were not broad, generic, class-wide prohibitions untethered to the disarmed person's propensity to commit unlawful violence. Rather, those analogues contemplated tailoring.

Subpart F expands on the well-known dissonance between contemporary over-criminalization and what might have given rise to a Founding-Era restriction on firearms possession. It provides an illustration of activity, in which a most prominent founder participated, that modernly could give rise to a permanent firearms ban. 


\section{A. Modern Cases and the Authority on Which They Rely}

The opinion in District of Columbia v. Heller, ${ }^{107}$ ancillary to its recognition of the right to bear arms as an individual right, ${ }^{108}$ provides dicta addressing felon disenfranchisement. It states, "[N]othing in our opinion should be taken to cast doubt on longstanding prohibitions on the possession of firearms by felons and the mentally ill, or laws forbidding the carrying of firearms in sensitive places such as schools and government buildings, or laws imposing conditions and qualifications on the commercial sale of arms." 109 A footnote indicates these longstanding prohibitions are merely presumptively lawful. ${ }^{110}$

Kevin Marshall notes that the Heller dicta concerning "longstanding" bans relies on gossamer authority. ${ }^{111}$ The Court did not endeavor to detail the nexus between that dicta and Founding-Era firearms restrictions. The above quote is preceded by the phrase, "[a]lthough we do not undertake an exhaustive historical analysis today of the full scope of the Second Amendment," 112 and the majority opinion makes few references to felons or felonies. ${ }^{113}$

The term "longstanding" appears to have been used in the Heller opinion simply for purposes of providing a consciously imprecise reference to a class of restrictions that were vaguely termed as "presumptively lawful." The discussion is not in the language of a rule or a standard. That

107554 U.S. 570 (2008).

108 Id. at 595 ("There seems to us no doubt, on the basis of both text and history, that the Second Amendment conferred an individual right to keep and bear arms.").

109 Id. at $626-27$.

$110 I d$. at 627 n. 26 ("We identify these presumptively lawful regulatory measures only as examples; our list does not purport to be exhaustive.").

111 Marshall, supra note 22, at 696-97.

The core of this article is an examination of the unsuitability of referencing whether persons are "virtuous" as a basis for allowing them to be permanently disarmed. Affirmatively stating the suitable contours of Second Amendment protection is a much wider undertaking and beyond the scope of this article. Lund cogently notes a starting-off point for such an investigation (although one might seek change the emphasis of the sources of identified purposes to emphasize the text and other objective sources): "When the text does not supply an adequately precise answer, a conscientiously originalist court has no choice but to decide the issue in light of the purpose of the provision as that purpose was understood by those who adopted it. This is not an algorithm . . . " Nelson Lund, The Second Amendment, Heller, and Originalist Jurisprudence, 56 UCLA L. REV. 1343, 1372 (2009).

112 Heller, 554 U.S. at 626.

113 The character string "felon" appears only four times in the majority opinion. In addition to the above reference, the opinion:

- references the Heller claimant receiving a license, upon success in the litigation, "if he is not a felon and is not insane;" Heller, 554 U.S. at 631; and

- twice, in discussing Lewis v. United States, 445 U.S. 55 (1980), describes "an appeal from a conviction for being a felon in possession of a firearm," Heller, 554 U.S. at 625 n.25, accompanied by a note that in Lewis, "The challenge was based on the contention that the prior felony conviction had been unconstitutional." Id. 
the dicta does not provide a rule, or even a governing standard, is elucidated by the incongruity of concluding that a practice is constitutional merely because it has been practiced for some decades, i.e., it is "longstanding." 114

Lower courts have attempted to shore up the doctrinal foundation of concluding felon disarmament is constitutional by referencing restricting constitutional rights to the virtuous. Although a few earlier cases referenced the "virtuous" in sketching the contours of the scope of firearms rights, ${ }^{115}$ at least based on citation tallies, ${ }^{116}$ reliance on this theory gained prominence in the contemporary Second Amendment with United States $v$. Vongxay. ${ }^{117}$ The conclusions seem driven in large measure by reference to a sketch of Founding-Era perspectives on firearms rights that is

114 E.g., United States v. Skoien, 614 F.3d 638, 641 (7th Cir. 2010) (en banc) ("It would be weird to say that $\S 922(\mathrm{~g})(9)$ is unconstitutional in 2010 but will become constitutional by 2043, when it will be as 'longstanding' as $\S 922(\mathrm{~g})(1)$ was when the Court decided Heller."). See also id. at 640 ("The opinion is not a comprehensive code; it is just an explanation for the Court's disposition. Judicial opinions must not be confused with statutes, and general expressions must be read in light of the subject under consideration.").

115 The first reported opinion involving firearms rights including the terms "virtuous" and "second amendment" is State v. Workman, 14 S.E. 9 (W. Va. 1891). The case involves a statute criminalizing the carrying of a revolver (or certain other dangerous weapons, not including rifles) outside his or her place of dwelling. $I d$. at 9 (reproduced in court-written syllabus). The statute did not criminalize public possession in transit to or from a place for repairing the arm. $I d$. The statute also provided a defense for a person the jury finds "a quiet and peaceable citizen, of good character and standing in the community in which he lives, [where] . . . he had good cause to believe ... that he was in danger of death or great bodily harm at the hands of another person, and that he was in good faith, carrying such weapon for self-defense and for no other purpose." Id.

The opinion construes the statute non-literally. As part of apparently discussing the constitutionality of the restriction, in light of "discrimination . . . between classes," the court indicates that a person without good character, although not benefitting from a "statutory" defense, "is left in the hands of the jury, under full protection of the common law and the constitution." Id. at 11. As to this issue, the court concludes, "This is a discrimination, it is true, between classes; but it is only a discrimination in favor of the virtuous class against the dangerous and vicious." $I d$.

116 A Westlaw search "adv: virtuous \& "second Amendment," sorted by Westlaw by "Most cited," lists fourth United States v. Vongxay, 594 F.3d 1111 (9th Cir. 2010). Only one of the three more-cited cases, United States v. McCane, 573 F.3d 1037, 1040 (10th Cir. 2009), predates Vongxay, and the Westlaw citation statistics suggest it is oft-cited for its Fourth Amendment analysis. As of May 25, 2020, Westlaw reported 89 citing references to McCane being to a headnote with a heading "Arrests and Stops," out of only 148.

A second competitor for most prominently cited initial authority on this matter, United States v. Yancey, 621 F.3d 681 (7th Cir. 2010), relies Vongxay:

Whatever the pedigree of the rule against even nonviolent felons possessing weapons (which was codified in federal law in 1938), most scholars of the Second Amendment agree that the right to bear arms was tied to the concept of a virtuous citizenry and that, accordingly, the government could disarm "unvirtuous citizens."

Yancey, 621 F.3d at 684-85 (citing Vongxay, 594 F.3d at 1118).

117594 F.3d at 1118. 
incomplete and ultimately off-point. The basic contours of the approaches these courts take are:

- First, the perceived need in the Founding Era for a virtuous citizenry arose from the need for an adequate militia.

However, omitted from these cases is dispositive evidence that, in the Founding Era, the general class of persons previously convicted of serious crimes, following any confinement, were actually disarmed in perpetuity.

- Second, the consequences of civil death, arising from conviction of a capital crime, involved forfeiture of assets. ${ }^{118}$

That, of course, does not speak to an ongoing forfeiture of arms, or a prohibition on their possession, after any initial forfeiture and any period of confinement for a person who, in the Founding Era, was not subject to capital punishment. ${ }^{119}$

We shall first examine Vongxay, as well as some other contemporary authority, then examine the authority on which this strand of caselaw relies, and then address omitted information.

In Vongxay, the court, in part quoting Don Kates, states:

Finally, we observe that most scholars of the Second Amendment agree that the right to bear arms was "inextricably ... tied to" the concept of a "virtuous citizen[ry]" that would protect society through "defensive use of arms against criminals, oppressive officials, and foreign enemies alike," and that "the right to bear arms does not preclude laws disarming the unvirtuous citizens (i.e. criminals) ...."We recognize, however, that the historical question has not been definitively resolved. ${ }^{120}$

118 See, e.g., infra note 142 and accompanying text.

119 See generally Marshall, supra note 22, at 715 (stating, as to one's being obligated to forfeit property at a particular time, "But it did not follow that one could not thereafter purchase and hold new personal property-including a gun.").

120 Id. (alterations in original) (citations omitted) (quoting Kates, supra note 9, at 146) (citing, inter alia, Marshall, supra note 22, at 714-28, and providing the following parenthetical summary of this portion of Marshall's discussion: "maintaining that bans on felon gun possession are neither long-standing nor supported by common law in the founding era"). In the article written by Kates that the court quotes, Kates further writes:

In classical republican political philosophy, the concept of a right to arms was inextricably and multifariously tied to that of the "virtuous citizen." Free and republican institutions were believed to be dependent upon civic virtu which, in turn, depended upon each citizen being armed-and, therefore, fearless, self-reliant, and upright. ... One implication of this emphasis on the virtuous citizen is that the right to arms does not preclude laws disarming the unvirtuous citizens (i.e., criminals) or those who, like children or the mentally unbalanced, are deemed incapable of virtue.

Kates, supra note 9, at 146. 
Reliance on this approach is common. ${ }^{121}$ A recent opinion from the D.C. Circuit conforms to this approach, with increased verbosity that continues to elide providing actual evidence of permanent, broad disarmament, post-sentence, of persons who had committed serious crimes in the Founding Era. ${ }^{122}$

Let us turn to what is provided in Kates' seminal academic works, on which Vongxay relies. ${ }^{123}$ Kates had written:

In classical republican political philosophy, the concept of a right to arms was inextricably and multifariously tied to that of the "virtuous citizen." Free and republican institutions were

Marshall identifies pre-Heller authority led astray by academic misreading of the historical traditions. Marshall describes United States v. Emerson, 270 F.3d 203, 226 n.21 (5th Cir. 2001), as relying on a law review article that conflates historical restrictions on voting, recognized in a 1903 treatise, with restrictions on firearms. Marshall, supra note 22 , at 709 .

121 See Binderup v. Att. Gen. U.S., 836 F.3d 336, 348 (3d Cir. 2016) (plurality opinion) (stating, "Several of our sister circuits endorse the 'virtuous citizen' justification for excluding felons and felon-equivalents from the Second Amendment's ambit. . . . People who have committed or are likely to commit 'violent offenses'-crimes 'in which violence (actual or attempted) is an element of the offense,'-undoubtedly qualify as 'unvirtuous citizens' who lack Second Amendment rights." (citation omitted) (quoting United States v. Skoien, 614 F.3d 638, 642 (7th Cir. 2010) (en banc)).

122 Medina v. Whitaker, 913 F.3d 152 (D.C. Cir. 2019), cert. denied sub nom. Medina v. Barr, 140 S. Ct. 645 (2019), states:

A number of other circuits have also considered this issue and have concluded that history and tradition support the disarmament of those who were not (or could not be) virtuous members of the community. At least four circuits have endorsed the view that "most scholars of the Second Amendment agree that the right to bear arms was tied to the concept of a virtuous citizenry and that, accordingly, the government could disarm 'unvirtuous citizens.' " The "virtuous citizen" theory is drawn from "classical republican political philosophy" and stresses that the "right to arms does not preclude laws disarming the unvirtuous (i.e. criminals) or those who, like children or the mentally imbalanced, are deemed incapable of virtue." Several circuits have relied on this theory to uphold the constitutionality of modern laws banning the possession of firearms by illegal aliens and juveniles-classes of people who might otherwise show, on a case-by-case basis, that they are not particularly dangerous. In considering these decisions, we recognize that there is "an ongoing debate among historians about the extent to which the right to bear arms in the founding period turned on concerns about the possessor's virtue." While we need not accept this theory outright, its support among courts and scholars serves as persuasive evidence that the scope of the Second Amendment was understood to exclude more than just individually identifiable dangerous individuals.

On balance, the historical evidence and the Supreme Court's discussion of felon disarmament laws leads us to reject the argument that non-dangerous felons have a right to bear arms.

Id. at 159 (citations omitted) (first quoting United States v. Yancey, 621 F.3d 681, 684-85

(7th Cir. 2010); then quoting United States v. Rene E., 583 F.3d 8, 15 (1st Cir. 2009) (quoting Reynolds, supra note 9, at 480); then quoting Rene E., 583 F.3d at 16).

123 See supra note 120. 
believed to be dependent upon civic virtu which, in turn, depended upon each citizen being armed-and, therefore, fearless, selfreliant, and upright. ... One implication of this emphasis on the virtuous citizen is that the right to arms does not preclude laws disarming the unvirtuous citizens (i.e., criminals) or those who, like children or the mentally unbalanced, are deemed incapable of virtue. ${ }^{124}$

Consider, further, the observations of Cornell and DeDino, in journal article body text and an accompanying footnote:

Those seeking pardon were not robbed of a right to free speech or free exercise of their religion, rights indisputably associated with individuals. Instead, the penalties deal more with the rights and obligations associated with a citizen's duty to society: participation in government as a political official, participation in the legal process as a juror, participation in the electoral process as a voter, and participation in the militia. ${ }^{139}$

139 The disqualifications are also similar in nature to the sorts of privileges taken away regularly from convicted felons today. ${ }^{125}$

One can assess the extent to which contemporary courts have relied on the relationship between the Second Amendment and a virtuous citizenry through a number of lenses. As a threshold matter, one might conclude that contemporary American society is not "virtuous," as that term was used in the Founding Era; thus, the Second Amendment should not be the fount of contemporary rights. ${ }^{126}$ We shall pass on that perspective, because it is inconsistent with Heller ${ }^{127}$ and McDonald. ${ }^{128}$

Alternatively it is apparently asserted by some that it is too administratively burdensome for courts to be required to make individualized determinations-it will produce an "avalanche of litigation." 129 Much as our society will not say the Fourth Amendment can

124 Kates, supra note 9, at 146. Vongxay also quotes Glenn Reynolds to that effect, although the citation is not meaningful but, rather, a judicial echo chamber; the cite is to Reynolds reiterating Kates. Vongxay, 594 F.3d at 1118 (quoting Reynolds, supra note 9, at 480).

125 Saul Cornell \& Nathan DeDino, A Well Regulated Right: The Early American Origins of Gun Control, 73 FordHAM L. REV. 487, 508 \& n.139 (2004).

126 See generally Williams, supra note 104, at 561 (examining Wendy Brown's assertion that she "cannot imagine a less appropriate appellation for the contemporary American Citizenry, which bears a shared commitment to almost nothing, least of all a common good." (quoting Wendy Brown, Guns, Cowboys, Philadelphia Mayors, and Civic Republicanism: On Sanford Levinson's The Embarrassing Second Amendment, 99 YaLE L.J. 661, 663 (1989)).

127 District of Columbia v. Heller, 554 U.S. 570 (2008).

128 McDonald v. City of Chicago, 561 U.S. 742 (2010).

129 Justice Stevens remarked as follows in dissenting as to applying the Second Amendment to the states, "[T]oday's decision invites an avalanche of litigation that could 
be ignored, because it enmeshes courts in constant litigation concerning the validity of searches, it also cannot properly state that it is satisfactory to deprive a class of persons broadly of their Second Amendment rights because requiring additional individualized evidence will give rise to a significant amount of litigation. This approach is also, of course, inconsistent with the contemporary political movement urging adoption of "Red-Flag Laws" creating judicial procedures for deprivation of firearms rights untethered to criminal convictions. ${ }^{130}$ A judiciary that the political process concludes has enough capacity to deprive persons of constitutional rights has enough capacity to restore them.

There is a separate issue as to whether courts are competent to make assessments of future danger. Lawrence Rosenthal has written, "Perhaps only those convicted of felonies regarded as dangerous should be barred from possessing firearms, as some commentators have argued. This approach, however, would enmesh courts in the difficult predictive business of judging which felonies present unacceptable risk of future firearms-related misconduct, a type of judgment alien to the framing-era regime."131 Again, the solution to the circumstance that it is difficult for a court to make a decision is not to eliminate broadly, in a summary process, a constitutional right. That mistakes may be made in some cases is not a reason unjustifiably to deprive other people, on a wholesale basis, of a constitutional right. And, as we shall see, ${ }^{132}$ Rosenthal's last point, concerning that sort of judicial weighing being "alien" in the Founding Era, is manifestly in error.

Rather, we shall examine the reliability and comprehensiveness of the authority Kates presents, and the extent to which acts that currently give rise to permanent firearms bans correspond to circumstances giving rise to firearm bans in the Founding Era.

mire the federal courts in fine-grained determinations about which state and local regulations comport with the Heller right-the precise contours of which are far from pellucid-under a standard of review we have not even established." McDonald, 561 U.S. at 904 (Stevens, J., dissenting). See, e.g., Bonidy v. U.S. Postal Serv., 790 F.3d 1121, 1128 (10th Cir. 2015) (stating, in justifying a general rule prohibiting firearms possession on post office property, "Under a more nuanced or discretionary regime, problems of perceived unfairness or unreasonableness - and accompanying litigation-would likely multiply, not disappear.").

130 See generally Red Flag Laws: Examining Guidelines for State Action: Hearing Before the S. Judiciary Comm., 116th Cong. (2019) 3 (Statement of David B. Kopel), https:// www.judiciary.senate.gov/imo/media/doc/Kopel\%20Testimony1.pdf (discussing various proposals and enactments, and concluding, "Nearly a third of such orders are improperly issued against innocent people.”).

131 Rosenthal, supra note 35 , at 1218 \& n.148 (footnote omitted) (providing inapt authority not referencing the Founding Era but, rather, difficulty in application of a contemporary statute).

132 See infra Part V.E (discussing bonds). 


\section{B. Linking the "Virtuous" to the Need for a Militia}

Does not Demonstrate All Persons Previously Convicted of Serious Crimes Were Actually Disarmed. Cases linking the scope of the Second Amendment to the Founding-Era conceptualization of the militia and a virtuous citizenry, and the authority on which these cases rely, are founded on abstract analyses. They do not provide evidence of a widespread understanding in the Founding Era, evidenced by widespread practice throughout the land at that time, that persons with prior convictions were, post-sentence, subject to permanent firearms bans. It is, frankly astonishing a court would modernly opt to curtail an enumerated right based on a theoretical assessment of the underpinnings of the need for a militia, as conceptualized in the Founding Era, without clear, direct evidence that those previously convicted of serious crimes were subject to wholesale, permanent disarmament in the Founding Era.

We shall below detail the actual mechanisms that were present in the Founding Era to address dangerous persons, post-sentence. ${ }^{133}$ As we shall see, those tools involved nuanced, context-specific mechanisms. They do not provide a basis for validating the overbroad wholesale, permanent prohibitions in current law.

Separately, in the Founding Era, human life was conceptualized as a divine gift that the recipient was under an affirmative obligation to protect. ${ }^{134}$ Bearing arms for self-defense was a means for discharging this duty. So, relying on this view-that Founding-Era norms contemplated persons post-sentence ought to be broadly disarmed-would require some clear indication that the event giving rise to disarmament sufficiently

133 See infra Part V.E.

134 Dwight Duncan and Peter Lubin write, "To understand what Jefferson meant by 'inalienable rights to life [and] liberty' we have to look to Locke's Second Treatise." Dwight G. Duncan \& Peter Lubin, The Use and Abuse of History in Compassion in Dying, 20 HARV. J.L. \& PuB. PoL'Y 175, 205 (1996). They continue, quoting, inter alia, a portion of Locke's chapter on "The State of Nature," to the following effect: "Every one as he is bound to preserve himself, and not to quit his Station wilfully . . .." Id. (quoting JoHn Locke, Two Treatises of Government 270-71 (Peter Laslett ed., 1988) (emphasis in original). Thomas McAffee and Michael Quinlan write, "In fact, speaking from a tradition that is as much republican as liberal, many advocates of this period referred to a duty of self-preservation as warranting armed resistance, as much as a right of self-defense." Thomas B. McAffee \& Michael J. Quinlan, Bringing Forward the Right to Keep and Bear Arms: Do Text, History, or Precedent Stand in the Way?, 75 N.C. L. REV. 781, 842 n.201 (1997). They reference a Founding-Era sermon that they describe as "enjoining the people to 'furnish themselves with weapons proper for their defense and learn the use of them' [and] "arguing that '[m]en are bound to preserve their own lives,' and refusal to act on this duty is 'criminal in the sight of God.' "Id. (quoting Simeon Howard, A Sermon Preached to the Ancient and Honorable Artillery Company in Boston (1773), in 1 American Political Writing During The Founding ERA (1760-1805), at 185, 197, 201 (Charles S. Hyneman \& Donald S. Lutz eds., 1983). 
tainted the wrongdoer's life so that this obligation to protect it, with the tools available, no longer existed.

Inconsistent with Heller, Which Rejects Linking the Second Amendment to Militia Service. To say that the need for a virtuous citizenry was linked to the need for a militia as a logical matter says nothing about whether those deemed "non-virtuous" can be disarmed. This style of thought is akin to concluding that because one reason to close a dwelling's windows is to prevent rain infiltration, one need not adopt the crime prevention strategy of closing one's home windows during sunny workdays to prevent burglaries.

The fallacy arises from implicitly treating one purpose for the operative text in the Second Amendment as its sole purpose that therefore curtails the operative provision. Of course, controlling American constitutional law directly rejects cabining the Second Amendment to militia-related activity. Heller notes, "The prefatory clause does not suggest that preserving the militia was the only reason Americans valued the ancient right; most undoubtedly thought it even more important for self-defense and hunting." 135 And Heller directly rejected the argument, proffered by the District of Columbia, that the Second Amendment "protects only the right to possess and carry a firearm in connection with militia service." 136

Relatedly, there is a manifest dissonance that would arise from this militia-centric conceptualization. As Heller notes, the original federal militia act excluded women and persons over the age of $45 .{ }^{137}$ As Jeffrey Giancana has noted, ${ }^{138}$ the Second Militia Act of $1792^{139}$ does not expressly exclude, from the militia requirement to possess arms, all persons

135 District of Columbia v. Heller, 554 U.S. 570, 599 (2008).

136 Heller, 554 U.S. at 577 (providing this summary of the District of Columbia's position-a position the court ultimately rejects).

137 Heller, 554 U.S. at 596 (citing An Act More Effectually to Provide for the National Defence by Establishing an Uniform Militia Throughout the United States, ch. 33, § 1, 1 Stat. 271, 271 (1792) (current version at 10 U.S.C. §§ 246-247 (Westlaw through Pub. L. No. 116-91)) (confusingly referencing this act as the "first Militia Act"). In 1792, a first Militia Act was passed on May 2. An Act to Provide for Calling Forth the Militia to Execute the Laws of the Union, Suppress Insurrections and Repel Invasions, ch. 28, 1 Stat. 264 (1792), repealed by An Act to Provide for Calling Forth the Militia to Execute the Laws of the Union, Suppress Insurrections, and Repel Invasions; and to Repeal the Act Now in Force for Those Purposes, ch. 36, § 10, 1 Stat. 424, 425 (1795); and a second Militia Act was passed on May 8. 1 Stat. 271 (1792). See, e.g., Parker v. District of Columbia, 478 F.3d 370, 386-87 \& n.11 (D.C. Cir. 2007) (referencing "the second Militia Act of 1792"), aff'd sub nom. District of Columbia v. Heller, 554 U.S. 570 (2008).

138 Jeffrey Giancana, Note, The "Scourge" of Armed Check Fraud: A Constitutional Framework for Prohibited Possessor Laws, 51 U. Mich. J.L. REFoRM 409, 416 (2018) (stating a mandate in the act "to purchase a firearm lacked a carved-out exemption for felons.").

139 Second Militia Act $\S \S 1,2,1$ Stat. 271, 271-72. 
previously convicted of serious crimes. It is a non-sequitur to say the Founding-Era conceptualization of the militia compels the conclusion that a class of persons (those with prior criminal convictions of some sort) do not benefit from an express constitutional right, when:

(i) there is no salient evidence members of that class were excluded, on a wholesale basis, from the militia duties of firearms ownership; and

(ii) it is not seriously claimed that the classes of persons who were expressly excluded from federal militia duties in the Founding Era (women and those over forty-five) do not benefit from the Second Amendment.

Now, perhaps there was some practice, not reflected in statutory language, excluding criminals, post-sentence, from any and all militia obligation that escapes identification in contemporary judicial opinions. In any case, any Founding Era nexus between militia obligations and prior convictions was not sufficiently widespread and salient-core to the Founding-Era understanding of firearms rights - to compel the conclusion that the operative clause of the Second Amendment is subject to an implicit limit that, as we shall see, ${ }^{140}$ relies on a wholly discredited constitutional theory.

\section{Forfeiture for Capital Crime}

The relevant contemporary caselaw references the Founding-Era treatment of persons convicted of capital crimes. Medina v. Whitaker ${ }^{141}$ notes, "In 1769, William Blackstone defined felony as 'an offense which occasions a total forfeiture of either lands, or goods, or both, at the common law, and to which capital or other punishment may be superadded, according to the degree of guilt." 142 Yet, the opinion then notes, "Felonies were so connected with capital punishment that it was 'hard to separate them.' "143 Notwithstanding the implicit link between imposition of capital punishment and forfeiture it just recognized, the Medina opinion proceeds to treat Founding-Era principles governing forfeiture as informing Founding-Era treatment of persons who were not given capital punishment:

[F] elonies were-and remain - the most serious category of crime deemed by the legislature to reflect "grave misjudgment and maladjustment." With this perspective, it is difficult to conclude that the public, in 1791, would have understood someone facing

140 See infra Part VI.

141913 F.3d 152 (D.C. Cir. 2019), cert. denied sub nom. Medina v. Barr, 140 S. Ct. 645 (2019).

142 Medina, 913 F.3d at 158 (quoting 4 William Blackstone, Commentaries *95 (Harper ed. 1854)).

143 Id. (quoting 4 Blackstone, supra note 142 , at *98). 
death and estate forfeiture to be within the scope of those entitled to possess arms. ${ }^{144}$

Missing from the opinion is articulation of a rationale why theoretical musings about the underpinnings of the treatment of persons sentenced to death in the Founding Era is sufficient to compel a conclusion concerning how courts should interpret a constitutional right.

Erroneously Equating Founding-Era Capital Crimes with All Serious Crimes. Attributes of civil death in the Founding Era would have included forfeiture of assets ${ }^{145}$ and an inability to enforce contracts ${ }^{146}$ or otherwise to initiate litigation. ${ }^{147}$ It is not the case that in the Founding Era, all crimes having "serious" punishments were capital. A 1749 Massachusetts act imposed three years imprisonment, and other punishments, for anonymous extortion. ${ }^{148}$ A 1790 federal statute imposed imprisonment of up to seven years, and a fine or possibly other ancillary punishments, for conviction of numerous crimes such as:

- misprison of treason;149

- maliciously maiming a person "within any of the places upon the land under the sole and exclusive jurisdiction of the United States, or upon the high seas, in any vessel belonging to the United States, or to any citizen or citizens thereof," and ${ }^{150}$

- destruction, etc., of records of courts of the United States. ${ }^{151}$

Numerous other crimes were punishable under that statute by imprisonment for more than one year, such as:

144 Medina, 913 F.3d at 158 (first quoting Will Tress, Unintended Collateral Consequences: Defining Felony in the Early American Republic, 57 Clev. ST. L. Rev. 461, 468, 473 (2009); then quoting Hamilton v. Pallozzi, 848 F.3d 614, 626 (4th Cir. 2017)).

145 See infra note 188 and accompanying text.

146 See Marshall, supra note 22, at 715.

147 E.g., 1 J. Chitty, A Practical Treatise on the Criminal LaW 725 (London, A.J. Valpy 1816) (stating "he can bring no action, nor perform any of the legal functions which before he was admitted to discharge"); Holmes v. King, 113 So. 274, 275 (Ala. 1927).

148 Act of 1749, ch. 234, § 1, reprinted in The Charters and General Laws of the Colony and Province of Massachusetts Bay 570 (Boston, T.B. Wait \& Co. 1814) (providing the following punishment for anonymous extortion: "sitting on the gallows for the space of one hour, with a rope around his, her or their neck, and afterwards shall be set upon the pillory, in their have one of his, her or their ears cut off," and three years of imprisonment while "kept to hard work," and whipping each three months.).

A 1711 Massachusetts act imposed for robbery "of another travelling the common road or highway" a punishment of six months imprisonment, "burning in the forehead or hand," and treble damages; a second conviction was a capital offense. An Act for Suppressing of Robberies and Assaults (1711), ch. 103, § 1, reprinted in The ChARTERs AND GEnERAL LAws of the Colony and Province of Massachusetts Bay 392, 393 (Boston, T.B. Wait \& Co. 1814).

149 An Act for the Punishment of Certain Crimes Against the United States, ch. 9, § 2, 1 Stat. 112, 112 (1790) (act codified as amended in scattered sections).

$150 \quad I d . \S 13,1$ Stat. at 115.

151 Id. $\S 15,1$ Stat. at $115-16$. 
- misprison of murder or other felony on the high seas or property under the exclusive jurisdiction of the United States (up to 3 years); 152

- manslaughter on property within the exclusive jurisdiction of the United States (up to 3 years);153

- confederacy to become a pirate (up to three years);154

- perjury in the courts of the United States (up to three years);155 and

- bribery of a federal judge ("fined and imprisoned at the discretion of the court"). ${ }^{156}$

The federal statute expressly provided that a conviction for none of those serious crimes "shall work corruption of blood, or any forfeiture of estate." 157 So, it simply was not the case that in the Founding Era, all serious crimes were accompanied by civil death and forfeiture of one's assets. ${ }^{158}$

These specific statutes referenced above are set forth merely for purposes of providing discrete, incontrovertible illustrations. One interested in a broader conclusion could turn to the Chitty treatise, which states, "[A]ll those offences which exist at common law, and have not been regulated by any particular statute, are within the discretion of the court to punish." 159 In sum, a diminished role of capital punishment arose from a combination of statutory revision and liberal reduction of charges by grand juries. ${ }^{160}$

$152 \quad I d . \S 6,1$ Stat. at 113.

$153 \quad$ Id. $\S 7,1$ Stat. at 113.

$154 \quad I d . \S 12,1$ Stat. at 115.

155 Id. $\S 18,1$ Stat. at 116.

$156 \quad$ Id. $\S 21,1$ Stat. at 117.

157 Id. $\S 24,1$ Stat. at 117.

158 See also, e.g., Boardman v. Gore, 15 Mass. 331, 337 (1819) (“These reasons do not exist with us. There is no forfeiture of lands or goods on conviction of crimes; nor is there any recompense provided by the public; nor is the criminal party punished with death ....").

1591 ChiтTY, supra note 147 , at 710 .

160 See, e.g., 1 Wayne R. LaFave et Al., Criminal Procedure § 1.6(b) (4th ed. Westlaw through Dec. 2019) ("As to punishment, although the colonial criminal law was harsh by modern standards, it was considerably less severe than English law. In part that was due to changes in the severity of authorized punishment, but more significant was the utilization of a sentencing scheme that gave officials discretionary authority to be lenient in order that the penalty actually imposed take account of the 'circumstances of the criminal [and] not just the crime.' Some colonies (most notably Pennsylvania) sharply reduced the number of offenses for which capital punishment could be imposed, but the more critical elements in the less frequent use of that penalty were the willingness of grand juries to downgrade charges to non-capital offenses, the willingness of juries similarly to convict on lesser offenses, liberal exercise of the power to pardon, and the ready availability of benefit of clergy in some colonies for first-offenders convicted of capital crimes." (footnotes omitted) (quoting David J. Rothman, The Discovery of the Asylum: Social Order AND Disorder IN the New Republic 50 (1971))); Donald Braman, Punishment and Accountability: 
Forfeiture Associated with Imposition of Capital Punishment, or Sometimes Incarceration for Life. As a general matter, civil death was linked to imposition of a capital sentence. ${ }^{161}$ The chapter on civil death (attainder) in Chitty's 1816 treatise on criminal law begins, "When sentence has been pronounced upon a criminal for a capital offense, he is immediately by operation of law placed in a state of attainder." 162 The text later states, "The word attainder is derived from the Latin term attinctus, signifying stained or polluted, and includes, in its meaning, all those disabilities which flow from a capital sentence." 163

One can assess the nature of the nexus by noting what a Missouri court, in the nineteenth century, needed to reference in identifying civil death not linked to imposition of a capital sentence: conviction for supporting a foreign government, and the Pope in particular. ${ }^{164}$

One can encounter some variation from this general principle. An example would be a statute providing for the administration of the estate of a person sentenced for life as if dead in fact. ${ }^{165}$ Another example would be "imprisonment for life and the loss of all the profits of his lands, with the forfeiture of the whole of his personal estate," for "having rescued an offender from any of the superior courts." 166

Understanding and Reforming Criminal Sanctions in America, 53 UCLA L. Rev. 1143, 1168-69 (2006) ("In colonial America, many formal and informal sanctions focused attention on the claims that others in the community had on the offender. The most typical forms of punishment were fines, the posting of bond, and sureties, with shaming, corporal punishment, banishment, and the death penalty also employed, though less frequently." (footnotes omitted)).

161 See generally Marshall, supra note 22, at 715 (stating the following generalization (some small adjustments to which we shall provide below, see infra notes 165-166 and accompanying text), "No death sentence meant no property disability.").

Chitty clarifies that consequences of civil death do not include forfeiture of all rights, so that one is transmuted into property to be trifled with at anyone's pleasure. Chitty writes, "[T] he person of an attainted felon is still under the protection of the law, and therefore the position of Blackstone, "that the law takes no further care of him than barely to see him executed,' must be taken with some allowance. To kill him without warrant is murder ...." 1 ChitTy, supra note 147, at 726 (footnotes omitted) (quoting 4 William Blackstone, COMMENTARIES *380).

1621 CHITTY, supra note 147, at 723 (first emphasis added).

1631 CHITTY, supra note 147, at 725 (last emphasis added).

164 Murphy \& Glover Test-Oath Cases, 41 Mo. 339, 344 (1867) ("Death was not always the consequence of an attainder. For instance, a party attainted of a præmunire did not forfeit his life; death was not the penalty attached to a judgment in such cases.").

165 Holmes v. King, 113 So. 274, 276 (Ala. 1927) ("A statute of Missouri, declaring a convict sentenced for life 'shall thereafter be deemed civilly dead,' provides, also, for the administration of his estate as if dead in fact." (quoting Williams v. Shackleford, 11 S.W. 222, 222 (Mo. 1889)). But cf. Platner v. Sherwood, 6 Johns. Ch. 118, 124-25 (N.Y. Ch. 1822) ("It seems, then, that perpetual imprisonment, or perpetual banishment without forfeiture of the estate, did not, in England, produce civil death, or, at least, did not devest the party of his estate.").

1661 CHITTY, supra note 147 , at 707 (emphasis removed). 
For our purposes, then, one might focus on the fact that civil death was typically linked to imposition of a capital sentence, although some of the consequences might attend a life sentence. And there might be some other ancillary exceptions. In any case, this variation shows that, in the Founding Era, forfeiture was from coextensive with commission of each and every "serious" crime.

And there is authority from long ago expressly stating that forfeiture of rights upon a conviction did not fully extend to one no longer confined: "And, upon obtaining a parole, in the absence of express restrictions, he is restored to his liberty to go at large and to his natural right to the fruits of his own labor so long as he lives up to the conditions of the parole. This would logically carry with it the right to make contracts and to acquire and dispose of his own private property."167

American Tradition Restricted Application of Civil Death. The American approach did not adopt the full scope of the common law civil death. ${ }^{168}$ The Supreme Court of Oklahoma stated as to statutes providing for civil death arising from a felony conviction, "[T] he full significance of such statutes have never been enforced by our courts for the principal reason that they are out of harmony with the spirit of our fundamental laws and with other provisions of statutes." 169 Similarly, Holmes v. King notes, "In the absence of statute, the doctrine of 'civil death' has been generally denied in this country." 170 Chadwick $v$. Knox states a convict in prison can contract for otherwise lawful services for assistance with seeking a pardon-which would be inconsistent with the notion that he or she was, in full, civilly dead. ${ }^{171}$

Over hundred years ago, the Oklahoma Supreme Court distinguished the treatment of a felon's natural rights and other legal rights, noting a modern trend under which natural rights are not abridged other than by express statutory provision. ${ }^{172}$ Similarly, Miller v. Turner ${ }^{173}$ also separately treats restriction of natural rights. The court states the collateral consequences of a conviction do not include limits on making

167 Byers v. Sun Sav. Bank, 139 P. 948, 950 (Okla. 1914).

168 See Marshall, supra note 22, at 715 (stating "the[] doctrines did not carry over to the United States in their strict English form").

169 Byers, 139 P. at 949.

170113 So. at 275.

17131 N.H. 226, 235 (N.H. Super. Ct. Judicature 1855) (stating he "may employ another to do such acts as may be rightfully and properly done for his relief, and contract to pay him for his services and to repay him his expenses. Such a contract . . is free from any just exception, and binding upon the parties.").

172 Byers, 139 P. at 949 (referencing a "modern trend ... to extend, rather than to limit, those natural rights ... except in states where they are expressly abridged by statute").

173253 N.W. 437 (N.D. 1934). 
contracts and maintaining actions "which concern his personal liberty and are based on natural rights as distinguished from legal rights." 174

In sum, the American tradition was not one of exuberant implementation of the ancient regime of civil death. The American tradition is limited to restrictions expressly adopted by statute, particularly as to natural rights. Of course, the right to bear arms is classified as a natural right. ${ }^{175}$ Understanding the contemporary authority does not point to Founding Era statutes broadly imposing permanent firearms disabilities, post-sentence, for each and every "serious" crime, it is inconsistent with the American experience to say that those broad restrictions are engrained in the American tradition.

The law in a colony, on the other hand, could expressly restrict firearms possession in identified, limited circumstances post-sentence, as revealed by study of an early nineteenth century compendium of Massachusetts law assembling acts from and after the mid-seventeenth century. A search of that book revealed Massachusetts acts expressly providing for forfeiture of arms for only a limited subset of serious crimes. Under a 1692 Massachusetts act, conviction of affray required the offender's imprisonment "until he find sureties for the peace and good behavior," and forfeiture of "his armour or weapons" as well as a potential fine. ${ }^{176}$ The only other remotely apt reference in that compendium of Massachusetts law, revealed by an electronic search, to a forfeiture and either "weapons" or "armour" is not specific as to those items. ${ }^{177}$ It involves

174253 N.W. at 439.

175 E.g., District of Columbia v. Heller, 554 U.S. 570, 593-94, (2008) ("Blackstone, whose works, we have said, 'constituted the preeminent authority on English law for the founding generation,' cited the arms provision of the Bill of Rights as one of the fundamental rights of Englishmen. . . . It was, he said, 'the natural right of resistance and self-preservation' . . . ." (citations omitted) (quoting Alden v. Maine, 527 U.S. 706, 715 (1999); then quoting 4 William Blackstone, Commentaries *139); id. at 594 (referencing additional authority); Nunn v. State, 1 Ga. 243, 251 (1846) (referencing a person's "natural right of self-defence, or of his constitutional right to keep and bear arms"); see United States v. Cruikshank, 92 U.S. 542, 553 (1875) (describing the Second Amendment in the following terms, "This is not a right granted by the Constitution. Neither is it in any manner dependent upon that instrument for its existence.").

176 An Act for the Punishing of Criminal Offenders (1692), ch. 11, §6, reprinted in THE Charters and General Laws of the Colony and Province of Massachusetts Bay 237, 240 (Boston, T.B. Wait \& Co. 1814). The only other reference to "affray" in that compendium of Massachusetts law, as of the early Nineteenth Century, is in a 1719 act concerning dueling, etc., which does not reference forfeiture of weapons. Act for the Punishing and Preventing of Dueling (1719), ch. 131, § 1, reprinted in THE ChARTERS AND General Laws of the Colony and Province of Massachusetts Bay 422, 422 (Boston, T.B. Wait \& Co. 1814).

177 According to an electronic search, a word with the stem "forfeit" appears within two pages of "weapon" or "weapons" or "armour" on 16 pages of that book, according to a search of the book in the database, The Making of Modern Law: Primary Sources, Gale Cengage Learning. ("Armor" does not appear.) Twelve are manifestly irrelevant to our issue, involving forfeiture of land, ThE CHARTERs AND GENERAL LAWS OF THE COLONY AND 
a 1751 act criminalizing the armed participation in rioting of twelve or more persons, and failure to disperse after an hour of order. ${ }^{178}$ That act provided for forfeiture of all one's land and goods ("or such a part thereof as shall be adjudged by the justices before whom such offense shall be tried"), in addition to whipping and one year's imprisonment. ${ }^{179}$

This illustration appears to be representative. Kevin Marshall, apparently in connection with recounting the state of the law up to the publication of a 1903 treatise, writes, "The closest thing to a case considering a felon disability, in 1878, struck down a regulation of pistol carrying to the extent that it required forfeiting the offending pistol upon a conviction. The law did not ban the offender from obtaining a new pistol." 180

Ameliorated by Benefit of Clergy. It would appear that one cannot assess the nature of collateral consequences of convictions for capital crimes without referencing the broader context. In the Founding Era, the harsh consequences of a conviction for a capital crime could be ameliorated by benefit of clergy in at least some colonies. ${ }^{181}$ This procedure, of course,

Province of Massachusetts Bay 133 (Boston, T.B. Wait \& Co. 1814); money, id. at 238, 241, 340, 344, 420, 468, 469, 470, 596, 597; and goods seized by impost officers, id. at 574 . The remaining four consist of: forfeiture of money for falsely sounding an alarm by firing a gun, id. at 343; a non-responsive reference to forfeiture where the reference to weapons is in a different act on the same page, $i d$. at 574; the reference discussed supra note 176 and accompanying text; and the reference discussed infra note 178. The term "gun" or "guns" appears ten times, none of which is relevant. See id. at 133 (forfeiture of money for trading with Indians); $i d$. at 162 (directions for mounting of artillery); id. at 163 (monetary fine for shooting guns in false alarm); $i d$. at 190 (monetary fine for masters of ships or seamen shooting gun after daylight or on the sabbath); id. at 261 (militia ownership of guns); id. at 266 (firing guns to sound an alarm); id. at 343 (fine for shooting gun after sunset, other than for an alarm or "necessary defense"); id. at 734 (providing weapons instruction for youths); id. at 802 (providing mandatory weapons ownership in an act for reinforcement of the army); id. at 804 (authorizing the paid appropriation of private arms to support the army).

178 An Act for Preventing and Suppressing of Riots, Routs, and Unlawful Assemblies (1751), ch. 239, § 1, reprinted in The Charters and General LaWs of the Colony and Province of MassachusetTs Bay 574, 575 (Boston, T.B. Wait \& Co. 1814).

$179 I d$. According to an electronic search of the version of the text published in The Making of Modern Law: Primary Sources, Gale Cengage Learning (visited May 6, 2020), the only two references to "pistol" are in statutes involving dueling, referenced supra note 176 and infra note 228 and accompanying text.

180 Marshall, supra note 22, at 710-11 (footnote omitted).

181 See, e.g., United States v. Browning, 24 F. Cas. 1276, 1277 (C.C.D.D.C. 1806) (describing an indictment for "stealing a tub of butter" as "charg[ing] a felony, and by the laws of Virginia, as they existed prior to 1796, its punishment was death, with the benefit of clergy"); State v. Pompey, 2 Del. Cas. 113, 113 (Quar. Sess. 1798) (summary of counsel's argument stating, "I have no doubt you will from the evidence find him guilty of manslaughter, which crime by our Act of Assembly entitles him to benefit of clergy or Act of Assembly, and, if he does, the court cannot hang him, but burn in the hand and imprison him six months."); State v. Gray, 5 N.C. 147, 147 (1806) ("No reason can at this day exist, why Females shall not be entitled to the benefit of Clergy, as well as Males."); LAFAVE ET 
seems bizarre from the contemporary perspective. But, in any case, it contemplated mitigation of the consequences of a capital conviction through a process involving, among other things, burning, branding or otherwise marking a convict's thumb-in general, benefit of clergy was available only once, ${ }^{182}$ and the marking provided some evidence of that ${ }^{183}$ —and a mitigated sentence, which could necessitate provision of a peace bond. For example, one opinion states, "Many persons have been admitted to the benefit of clergy in Maryland, and burnt in the hand ...." 184 One granted benefit of clergy was subject to a range of alternative punishments, including, among others, imprisonment for a term, a requirement to post a bond for good behavior and, for convictions in England, "transportation" 185 to colonial America or another a colony. ${ }^{186}$

This author has searched in vain for any reference in the English authority Chitty to a collateral consequence involving a permanent forfeiture of firearms rights - or, in fact, any forfeiture of firearms rights at all, except as might be necessitated in order to obtain a temporary bond. ${ }^{187}$

AL, supra note $160, \S 1.6(\mathrm{~b})$ (referencing "the ready availability of benefit of clergy in some colonies for first-offenders convicted of capital crimes"); Marshall, supra note 22, at 715 (briefly discussing benefit of clergy).

182 People v. Youngs, 1 Cai. 37, 39 (N.Y. Sup. Ct. 1803) (summary of counsel's argument, stating, "In England, the second conviction is not availed of in the indictment; but when the prisoner claims the benefit of his clergy, it is counterpleaded." (emphasis removed)); 1 CHITTY, supra note 147, at 675 (referencing a single use for persons not in holy orders; clergy allowed the benefit "as often as they may need it").

1831 CHITTY, supra note 147 , at 669.

184 United States v. Norris, 27 F. Cas. 187, 188 (C.C.D.C. 1807) (opinion of Cranch, C.J.).

185 See generally 2 William Hawkins, A Treatise of the Pleas of the Crown 508 (John Curwood ed., 8th ed. London, S. Sweet 1824) (stating, as to exile or transportation, and "send[ing] a subject of England ... out of the land," "After the establishment of English colonies in America, therefore, it became in this country, as in all others which have had colonies, the most common sentence of criminals.").

186 Chitty notes that a the end of the seventeenth century, for those granted benefit of clergy, "court[s] were authorized to commit the offenders to the house of correction, for any time not less than six months nor exceeding two years . . ." 1 CHITTY, supra note 147, at 672. The alternatives were subsequently expanded to include for some crimes "the offender to be transported for seven years to America, which has been since altered to any part of his majesty's colonies." Id. at 673; see generally id. at 711-15 (generally discussing the judicially-imposed punishments for clergyable offenses); id. at 714-15 (identifying specific illustrations, including in one case incarceration for a year and sureties for good behaviour for seven years; and, in another, imprisonment for two years, followed by an obligation to provide sureties for good behavior for three years, in addition to the pillory and a fine).

187 According to an electronic search of the text using interface provided by The Making of Modern Law: Legal Treatises 1800-1926 database (Gale Cengage Learning), the book has no responsive information (no reference to forfeiture of firearms, specifically, as revealed by searches for pages with the words with the stem "forfeit" within 90 words of any word with any of the following stems: arm, firearm, musket or weapon. In specific, the searches were: chitty and (forfeit* n90 arm*); chitty and (forfeit* n90 firearm*); chitty and (forfeit* n90 gun); chitty and (forfeit* n90 musket*); chitty and (forfeit* n90 weapon*). The 


\section{Kates' Historical Recitation Is Unpersuasive}

Above, this Part has addressed why two of the referenced snippets of historical conceptualizations-(i) the historical linking of a virtuous citizenry and the need for a militia and (ii) forfeitures imposed on persons sentenced to death-are insufficient to conclude there was an implied limit on the Second Amendment's scope in the Founding Era that necessitates validation of permanent felon firearms bans that are incongruous with contemporary constitutional norms applied elsewhere. We can now address the third historical justification: Kates' fragmentary recitation of some Founding-Era proposals.

Kates, whose seminal work has been relied upon by initial authority treating felon bans following Heller, further urges that the Second Amendment does not benefit persons with prior felony convictions, by referencing certain Founding-Era state proposals. He writes:

Felons simply did not fall within the benefits of the common law right to possess arms. That law punished felons with automatic forfeiture of all goods, usually accompanied by death. . . . Nor does it seem that the Founders considered felons within the common law right to arms or intended to confer any such right upon them. All the ratifying convention proposals which most explicitly detailed the recommended right-to-arms amendment excluded criminals and the violent. ${ }^{188}$

One can quickly identify numerous concerns with reliance on the authority Kates identifies as a basis to support his conclusions:189 it identifies only a few provisions; even this limited number did not all garner majority support; and the collection omits other Founding-Era proposals supporting the opposite conclusion.

Kates ultimately references the following proposals, a majority of which do not involve exclusions for non-dangerous persons, and only one of which he identifies as having garnered majority support from a state convention—one that excluded persons for engaging in "actual rebellion":

(i) a proposal from New Hampshire recommending a federal bill of rights allowing disarmament of "any citizen . . . as are or have been in actual rebellion;"190

following additional restriction was incorporated in each search (to exclude from the search other works): and Year of Publication: 1816.

188 Don B. Kates, Jr., Handgun Prohibition and the Original Meaning of the Second Amendment, 82 Mich. L. REV. 204, 266 (1983).

189 See generally Joseph G.S. Greenlee, The Historical Justification for Prohibiting Dangerous Persons from Possessing Arms, 20 Wyo. L. Rev. 249, 275 (2020) ("Kates's article, however, provides no meaningful support for the theory.").

190 Kates, supra note 188, at 222 (quoting 1 JonAthan Elliot, DeBATES IN THE SeVERAL State Conventions 326 (2d ed. 1836)). 
(ii) a proposal from a "rump" of the Pennsylvania delegates approving the federal constitution-a proposal that would have prohibited "disarming the people or any of them unless for crimes committed, or real danger of public injury from individuals;" 191 and

(iii) a proposal from Sam Adams limiting protected firearms rights to "peaceable citizens." 192

A Founding-Era proposal allowing disarmament of persons who have been "in actual rebellion" is completely different from wholesale disarmament, post-sentence, of all persons who have committed serious crimes, whether involving physical force or not.

Moreover, Kates' listing is not complete, at least insofar as his reference to proposals that "most explicitly detailed the recommended right-to-arms amendment excluded criminals and the violent"193 is not understood as a linguistic sham. Nicholas Johnson and co-authors note:

(i) Virginia proposed amendments that included, inter alia, "That the people have a right to keep and bear arms; that a well regulated militia composed of the body of the people trained to arms, is the proper, natural, and safe defence of a free state.”194

(ii) New York's ratification message included, inter alia, a statement "That the people have a right to keep and bear arms; that a well regulated militia, including the body of the people capable of bearing arms, is the proper, natural, and safe defence of a free state." 195

(iii) North Carolina's resolution of proposed amendments provided a declaration of rights including in pertinent part, "That the people have a right to keep and bear arms; that a well regulated militia, composed of the body of the people, trained to arms, is the proper, natural, and safe defence of a free state . . ."196

(iv) Rhode Island's ratification message included in pertinent part, "That the people have a right to keep and bear arms; that a well regulated militia, including the body of the people capable of bearing arms, is the proper, natural, and safe defence-of a free state . . ." 197

191 Id. at 222 (emphasis removed) (quoting 2 Bernard SchwARTz, The BiLl of Rights: A Documentary History 665 (1971)). This proposal was rejected. Nicholas J. JoHnson ET aL., Firearms Law and the Second Amendment: Regulation, Rights, and Policy 310 (2d ed. 2018).

$192 I d$. at 222 at 222 (quoting SchwARTZ, supra note 191, at 675). This proposal was rejected. JoHNSON ET AL., supra note 191, at 312.

193 See supra note 188 and accompanying text.

194 JOHNSON ET AL., supra note 191, at 322.

195 Id. at 325

196 Id. at 327

197 Id. at 328. 
None of these has an express exclusion for dangerous persons or persons with prior felony convictions.

Insofar as Kates' exclusion of these proposals was conscious, and then styled as limiting his sample to "explicitly detailed" proposals, that would be a sham, disguising the fact that the sampling process ab initio excludes proposals that do not support his conclusion. Those that do not support his conclusion are naturally written with phrasing he appears to classify as not "explicitly detailed." So indeed, 100\% of enactments and proposals having language used in a carve-out-a carve-out treating criminals, postsentence worse-have carve-outs. But that does not mean those without carve-outs ought to be disregarded, because they do not have carve-outs and, therefore, are not "explicitly detailed."

\section{E. Actual Founding-Era Limits}

The intellectual foundation for concluding those with any prior felony convictions are outside the scope of those who benefit from the Second Amendment, as we have shown, relies on assuming a broad class of persons was, in the Founding Era, deprived of firearms rights, without any direct authority whatsoever. ${ }^{198}$

Let us then review the actual Founding-Era prohibitions. This author is not aware of analogous Founding-Era federal prohibitions. ${ }^{199}$ One might be inclined to stop there. For example, there were religious restrictions on holding office in South Carolina under its 1778 constitution, ${ }^{200}$ and the state established "The Christian Protestant religion" as "the established religion of this State." 201 So, some caution is necessary before concluding an enumerated right protected by the Bill of Rights was subject to an

198 It may be that courts have concluded post-sentence restrictions on violent felons must be available, and have simply settled on the most plausible rationale that has come to their attention-albeit one that is over-inclusive. The following perhaps highlights the relevant concern:

For example, if the operative clause recognizes an individual right to possess and carry in case of confrontation all firearms in common civilian use, then there would seemingly be no textual basis to deprive some individuals of that right on the basis of a prior conviction or mental illness or to prevent individuals from exercising the right to carry firearms if concealed or in "sensitive places." While there may be good policy reasons for such regulations, Heller states that "[c]onstitutional rights are enshrined with the scope they were understood to have when the people adopted them, whether or not future legislatures or (yes) even future judges think that scope too broad." In this fashion, Heller's originalism breaks down.

Rosenthal, supra note 35, at 1194 (quoting District of Columbia v. Heller, 554 U.S. 570, 634-35 (2008)).

199 Marshall describes 1689 religion-based exclusions from firearms rights in England as, "the closest thing in the historical record, before World War I, to direct support for disarming felons.” Marshall, supra note 22, at 721.

200 See S.C. Const. OF 1778, arts. III, XII, XIII, https://avalon.law.yale.edu/ 18th_century/sc02.asp\#1.

201 Id. art. XXXVII. 
implicit exception merely because one can point to an idiosyncratic state restriction in the Founding Era. ${ }^{202}$

However, were one inclined to turn to state restrictions, it would appear there were not state restrictions comparable to the current federal felon prohibition. The closest state prohibitions that come to this author's attention, which are not comparable, include:

- Some provisions disarming "persons who refused to swear an oath of allegiance to the state or to the nation;"203 and

- More generally, restrictions and "law-abiding slaves, free blacks, and Loyalists" 204 — and other inapposite restrictions adopted in the shadow of the Revolutionary War;205 and

- Assorted circumstances under which dangerous persons might be required to post bonds. ${ }^{206}$

The third-listed mechanism is patently the most relevant. But let us first examine, in brief, the others. Lack of loyalty to one's government, and adhering to governments in opposition, in temporal proximity to the American Revolution, is qualitatively different from permanently disarming all persons who had previously committed any serious crimes. This historical analogue involves different classes of disarmed persons, it is much more narrow in scope, and it involves addressing misconduct involving harm to the core governance structure.

Rosenthal asserts, "Although, as Heller noted, framing-era regulation was limited, it was not insignificant. Classes of individuals such as slaves,

202 See generally Barron v. City of Baltimore, 32 U.S. 243, 247-48 (1833) ("If these propositions be correct, the fifth amendment must be understood as restraining the power of the general government, not as applicable to the states. In their several constitutions, they have imposed such restrictions on their respective governments, as their own wisdom suggested; such as they deemed most proper for themselves. It is a subject on which they judge exclusively, and with which others interfere no further than they are supposed to have a common interest.").

203 Nat'l Rifle Ass'n of Am. v. ATF, 700 F.3d 185, 200 (5th Cir. 2012).

204 Id. at 200. See also JoHnSON ET AL., supra note 191, at 280 ("American Tories who fought for the crown could be disarmed without compensation pursuant to the laws of war. . .. After the war was over, ... [a]s for the former Loyalists or neutrals who stayed in the United States, there were no legal restrictions on their acquisition of arms." A note asks the extent to which this informs the understanding of the Second Amendment. Id. See also Marshall, supra note 22, at 723-24 (discussing treatment by the Continental Congress of persons "notoriously disaffected to the cause of America," and similar treatment in assorted colonies). See generally Kopel \& Greenlee, supra note 65, at 244 ("[T] tradition-from 1791 or 1866 - of prohibiting gun possession . . . for people convicted of misdemeanors or subject to civil protective orders. The colonies and then the states certainly knew how to ban firearms possession for people who were considered dangerous (namely, slaves and Indians").).

205 See Greenlee, supra note 189, at 264-65 (discussing colonial restrictions adopted during the Revolutionary War applicable to "notoriously disaffected to the cause of America" and other restrictions of a similar scope).

206 See Johnson ET AL., supra note 191, at 379-81 (discussing bonds). 
freed blacks, and people of mixed race were frequently prohibited from owning or carrying guns, and some states extended this bar to Catholics or whites unwilling to swear allegiance to the Revolution." 207 One should think it self-evidently unsatisfactory to rely on manifestations of Founding-Era racial or religious discrimination and intolerance as a basis for justifying a contemporary treatment of other classes of persons. ${ }^{208}$

Rosenthal notes, "The prophylactic regulations of the framing era utilized proxies for dangerousness that we would today find wildly inaccurate, if not profoundly offensive, such as religion, race, and political loyalty."209 Rosenthal, however, elides the most salient Founding-Era "prophylactic regulations" 210 — use of bonds of limited duration.

Donald Braman writes:

In colonial America, many formal and informal sanctions focused attention on the claims that others in the community had on the offender. The most typical forms of punishment were fines, the posting of bond, and sureties, with shaming, corporal punishment, banishment, and the death penalty also employed, though less frequently. ${ }^{211}$

Some basic principles governing bonds are set forth in a Founding-Era treatise, sometimes referenced as Burn's Justice or Burns's Justice, ${ }^{212}$ that

207 Rosenthal, supra note 35, at 1210.

208 State V. Newsom, 27 N.C. 250 (1844), provides an illustration of the use of a historical restriction at the time of a constitutional provision's adoption as giving rise to an implicit limit. The case involves a challenge to a statute that required free blacks to obtain a license or keep at their houses or to carry. Id. at 250 (headnote). As to its compatibility with a state constitutional provision that protected firearms rights "for the defence of the state," id. at 253-54, the court in sum concludes the constitutional right was subject to an implicit limit derived from longstanding racial discrimination:

And, while we acknowledge the solemn obligations to obey the constitution, as well in spirit as in letter, we at the same time hold, that nothing should be interpolated into that instrument, which the people did not will. We are not at liberty to give an artificial and constrained interpretation to the language used, beyond its ordinary, popular and obvious meaning. Before, and at the time our constitution was framed, there was among us this class of people, and they were subjected to various disabilities, from which the white population was exempt. It is impossible to suppose, that the framers of the Bill of Rights did not have an eye to the existing state of things, and did not act with a full knowledge of the mixed population, for whom they were legislating.

Id. at 254 . So, a contemporary justification for restricting firearms rights eerily mimicks the odious path previously used to justify racial restrictions on firearms possession.

209 Rosenthal, supra note 35, at 1215.

210 See id. at 1190 n.23 (containing a sole use of a word having "bond" as its stem in the name of a cited article).

211 Braman, supra note 160, at 1168-69 (footnotes omitted).

212 Bradstreet v. Furgeson, 17 Wend. 181, 187 (N.Y. Sup. Ct. 1837) ("Most of the law upon the subject of 'surety for the peace,' and for 'good behavior,' will be found in Burns's Justice, a book of the highest authority in these matters . . .."). 
was published in multiple editions under various authors. ${ }^{213}$ The requirements in the Founding Era for a "surety for the peace" or a "surety for the good behaviour," two different types of sureties, are relevant. These provided nested restrictions-a surety for good behaviour subsumed the conduct covered by a surety for the peace. ${ }^{214}$

The mechanics governing these two types of bonds were similar, ${ }^{215}$ but not identical. The individual obligated to obtain the bond would need to arrange for one or more persons to provide sureties-persons who would forfeit money if the covered person committed some act during the bond's term. Often in the discretion of the justice, ${ }^{216}$ the surety could have been for a term, ${ }^{217}$ or it could have been for the covered person's life. ${ }^{218}$ The justice also had discretion in setting number of sureties, and the amount of the bond. ${ }^{219}$ If the ordered surety could not be obtained, the individual was subject to imprisonment. ${ }^{220}$

This process may have restricted firearms rights in two ways. First, there could have been an indirect impact. A review of the 1801 successor edition of Burn's Justice has not revealed the actual considerations of persons acting as sureties. However, one should think that one acting as surety might only be a surety for a physically dangerous person were the covered person's access to arms restricted. ${ }^{221}$ This would be consistent with an article referenced above, ${ }^{222}$ in which Braman writes:

A common combination of both formal and informal sanction was the assessing of bonds of surety for good behavior against the properties of the defendant and two members of the community willing to speak on the defendant's behalf. These bonds of surety, which friends pledged to pay if the offender did not maintain his

213 E.g., Mathew Carey, Preface to The Conductor Generalis: or, the Office, Duty And Authority of Justices of the Peace (Philadelphia, Charless, Printer 1801) [hereinafter CONDUCTOR GENERALIS] ("The prefent work was compiled from Burn's Juftice, previous to the late revolution; and was favoured with a very high degree of public approbation ....").

214 CONDUCTOR GENERALIS, supra note 213, at 335 ("[T]he good behaviour include[ed] the peace ....").

215 Conductor Generalis, supra note 213, at 335.

216 CONDUCTOR GEneralis, supra note 213, at 332 ("[I]t may be regulated by the difcretion of fuch juftice, both as to the number and fufficiency of the fureties, and the largenefs of the fum, and the continuance of the time for which the party fhall be bound."). See also infra note 229 (referencing judicial discretion to set a term of a peace bond following a conviction for dueling).

217 See supra note 216.

218 CONDUCTOR GENERALIS, supra note 213, at 332.

219 CONDUCTOR GENERALIS, supra note 213, at 332.

220 Conductor GEneralis, supra note 213, at 331.

221 Marshall, supra note 22, at 718-19.

222 See supra note 211 and accompanying text. 
good behavior, helped draw the community into the policing of the offender. ${ }^{223}$

Braman quotes a text as stating, "The two sureties required from neighbors, friends, or superiors to pressure the defendant to keep his pledge show that in deterrence, as in arrest and trial, the criminal justice system of the county depended upon the active assistance of the community." 224

Second, there was a direct restriction that appears less prominently identified. Although a bond for the peace would not be forfeited absent battery or affray, a bond on good behavior expressly limited some forms of weapons possession: "[T] he good behavior may be forfeited by the number of people a man has, and by their harnefs, or weapons, and the like, altho' they break not the peace." 225 So, to be clear, there were Founding-Era provisions directly regulating firearms possession of persons considered physically dangerous, but they were not triggered automatically to impose a permanent ban on all persons who had ever committed any serious crime.

Illustrations of Use of Bonds for Founding-Era Analogues. We have above noted that bonds were used in the Founding Era to restrict dangerous behavior of criminals, post-incarceration for some crimes. Let us now turn to providing illustrations of some of the crimes for which they were used.

Some of circumstances that would have justified requiring bonds for good behavior ${ }^{226}$ would not seem to be a suitable basis to impose any restriction modernly. But bonds were used to address, for example, domestic violence and sexual assault. ${ }^{227}$ A Massachusetts act imposed,

223 Braman, supra note 160 , at 1169 n.93.

224 Braman, supra note 160, at 1169 n.93 (quoting AM. HistoriCAL Ass'N, AMERICAN Legal Records: Criminal Proceedings in Colonial Virginia, at ix, lxxi (Peter Charles Hoffer \& William B. Scott eds., 1984)).

225 Conductor Generalis, supra note 213, at 337. That text later states that a bond for good behavior is forfeited "for going armed with great numbers to the terror of the people, or fpeaking words tending to fedition," identifying these acts as ones not triggering forfeiture of a surety of the peace. Id. at 346 .

226 See Conductor GenERALIS, supra note 213, at 342-43 (“[P]erfons of ill behaviour, or evil of fame or report generally, or that fhall keep company with any fuch, or with any other fufpicious perfon in the night[;] ... Sufpected perfons who live idly, and yet fare well, or are well apparelled, having nothing whereon to live; unlefs upon examination they fhall give a good account of fuch their living[;] . . . [the author of] a writing full of obfcene ribaldry, without any kind of reflection upon anyone, ... as a fcandalous perfon of evil fame.").

227 William Nelson states, for example, "[C]ourts required men who beat their wives to enter into peace bonds . . .." William E. Nelson, Law and the Structure of Power in Colonial Virginia, 48 VAL. U. L. REV. 757, 795 (2014). A 1761 Massachusetts act states that theretofore, conviction of "assaulting or offering any violence or insolence to any woman or woman kind in the fields, streets or lanes in any town, or of despoiling them[, etc.]," was to 
inter alia, a bond requirement on one convicted of dueling-the required bond term being changed in the first part of the eighteenth century to one year ${ }^{228}$ from "for so long a time as the . . court shall judge reasonable." 229 Posting a bond was, in fact, the ultimate consequence in Sir John Knight's Case, ${ }^{230}$ the seminal case addressing the seventeenth-century treatment of one who "with evil intent" 231 traveled with arms to terrify the people. Joseph Greenlee provides additional illustrations, including a three-year prohibition on bearing arms for treason in connection with Shays's Rebellion. ${ }^{232}$

\section{F. Modern Overcriminalization Having No Founding-Era Analogue}

Blocher and Miller note, "Unless courts construe Founding-era regulations at a higher level of abstraction, shorten the length of time for regulations to be considered long-standing, or both, few modern regulations will find indisputable support in Founding-era law."233 The contemporary federal firearms ban extends to some convictions for, for example, (i) driving while intoxicated ${ }^{234}$ and (ii) false alteration of government documentation allowing tinted vehicle windows, to extend it to a different vehicle. ${ }^{235}$ The brief authority Kates cites ${ }^{236}$ simply does not support the proposition, and does not provide a basis to conclude, it was intended in the Founding Era that firearms rights would be forfeited for activity equivalent to these illustrations.

It is not this article's purpose to assemble a comprehensive compilation of the relevant Founding Era illustrations. Let us, instead, turn to an example.

be publicly whipped or incarcerated for 30 days and to "find sureties for the good behavior before he be discharged." Act of 1761, ch. 288, reprinted in THE CHARTERS AND GENERAL Laws of the Colony and Province of Massachusetts Bay 644, 644 (Boston, T.B. Wait \& Co. 1814).

228 Act of 1729/1730, ch. 172, § 1, reprinted in The ChARTERs AND General LAWs of the Colony and Province of Massachusetts Bay 470-71 (Boston, T.B. Wait \& Co. 1814).

229 Act for the Punishing and Preventing of Dueling (1716), ch. 131, § 2, reprinted in The Charters and General Laws of the Colony and Province of Massachusetts Bay 422, 423 (Boston, T.B. Wait \& Co. 1814).

$230 \quad$ Sir John Knight's Case, (1686) 87 Eng. Rep. 75, 76 n.a (K.B.), additional proceedings at (1686) 90 Eng. Rep. 330 (K.B.).

231 The opinion references actions "malo animo," Sir John Knight's Case, 90 Eng. Rep. at 330 (emphasis added), defined in JoHnson ET AL., supra note 191, at 96, as "[w]ith evil intent; with malice."

232 Greenlee, supra note 189, at 268-69.

233 Blocher \& Miller, supra note 34, at 328 (footnote omitted). See generally Marshall, supra note 22 , at 697 (stating, "The need is particularly acute given the cancerous growth since the 1920s of 'regulatory' crimes punishable by more than a year in prison, as distinct from traditional common-law crimes.").

234 See supra notes 82, 94 and accompanying text.

235 See supra note 88 and accompanying text.

236 See supra note 190-192 and accompanying text. 
There is a federal prohibition on various types of insider trading in securities, ${ }^{237}$ for which willful violators are criminally punishable with up to twenty years imprisonment. ${ }^{238}$ A 2012 act expressly provides that members of Congress and employees of Congress are not excluded from the prohibition. $^{239}$ A conviction will give rise to a permanent firearms prohibition under some state law, ${ }^{240}$ and the theory generally excluding the non-virtuous from the Second Amendment would not invalidate this prohibition. It also may give rise to a permanent federal felon prohibition-there is limited authority as to whether it would be within the exception in the federal ban for commission of certain business practice crimes. ${ }^{241}$

23715 U.S.C. $\S 78 \mathrm{j}(\mathrm{b})$ (Westlaw through Pub. L. No. 116-91).

23815 U.S.C. $\$ 78 f f(a)$.

239 Stop Trading on Congressional Knowledge Act of 2012 (STOCK ACT), Pub. L. No. 112-105, § 4, 126 Stat. 291, 292 (2012) (“(a) AFFIRMATION OF NONEXEMPTION.Members of Congress and employees of Congress are not exempt from the insider trading prohibitions arising under the securities laws, including section 10(b) of the Securities Exchange Act of 1934 and Rule 10b-5 thereunder.").

240 See supra note 61 and accompanying text.

241 One case holds securities fraud, arising from with false filings with the Securities and Exchange Commission, is within the exception. Reyes v. Sessions, 342 F. Supp. 3d 141, 144, 156 (D.D.C. 2018). See supra note 52. It concluded the common theme identifying crimes within the exclusion is they are "commercial crimes intended to address economic harm to competitors or consumers." Id. at 150. However, it would appear that the purposes of this act are, rather, to assure "clean" government. The report on the act states:

The Committee nonetheless concluded that it is of the utmost importance for the American people to have full confidence that all Members of Congress act to serve the American people rather than their own financial interests. It therefore reported S. 2038 to establish a clear policy that insider trading will not be tolerated within the halls of Congress, and to ensure that any instances of insider trading by Members or their staff will be subject to the same civil and criminal laws that apply to everyone else.

S. Rep. 112-244, at 2-3 (2012).

Dicta in another case would indicate not. United States v. Geyler, 932 F.2d 1330, 1336 n.9 (9th Cir. 1991) (suggesting federal convictions for "mail fraud or securities fraud" are outside the exception), abrogated on other grounds by Beecham v. United States, 511 U.S. 368 (1994).

In any case, there has been no suggestion that an exception from felon prohibition for securities fraud or insider trading is constitutionally required. The Ninth Circuit, for example, vaguely implies that only much less serious crimes than insider trading or securities fraud are in jeopardy of being too insignificant for the Second Amendment to allow them to be predicate offenses for a permanent firearms ban. United States v. Phillips, 827 F.3d 1171 (9th Cir. 2016), notes:

Our holding does not address, however, the question of whether there are limits on Congress's and the States' ability to define any old crime as a felony and thereby use it as the basis for a $\S 922(\mathrm{~g})(1)$ conviction, consistent with the Second Amendment. . . . Can Congress or the States define petty larceny as a felony? Of course. Can a conviction for stealing a lollipop then serve as a basis under $\S 922(\mathrm{~g})(1)$ to ban a person for the rest of his life from ever possessing a firearm, consistent with the Second Amendment? That remains to be seen.

Id. at 1176 n.5. 
One supposes the founders would not have thought this type of activity equivalent of a capital crime-sufficiently egregious to deprive one of firearms rights. Why so? Because it was apparently practiced by intimates of the founders themselves.

Bowers discusses insider trading on Revolutionary War debt-debt that became much more valuable on its assumption by the federal government. $^{242}$ Bowers notes Alexander Hamilton's role in this speculation: "In all this, Hamilton had no part and no responsibility beyond having made indiscrete disclosures of which his friends availed themselves, through buying and selling through his agents in New York and Philadelphia for his brother-in-law." To express the principle in language parallel to that used in Medina $v$. Whitaker:243 With this perspective, it is difficult to conclude that the public, in 1791, would have understood someone who participated in acts of the type committed by intimates of founders, with Alexander Hamilton's indiscrete assistance, to be outside the scope of those entitled to possess arms.

\section{G. Conclusion}

Our brief review of the Founding-Era restrictions on criminals' firearms possession, post sentence, has revealed restrictions that are not analogous the contemporary firearms bans imposed on persons with prior felony convictions. The Founding-Era restrictions were tailored-their term varies depending on the nature of the crimes. That is in contrast to the current federal restrictions (and some state restrictions) that, absent reinstatement, are generally permanent ${ }^{244}$ and, other than for the wholesale exclusion of some business practices crimes, are independent of whether the prior activity is associated with any threat of future violence.

The scholarly fount of the jurisprudential position that the Second Amendment does not benefit those who have previously committed "serious" crimes and are therefore not "virtuous" relies on a censored sampling of Founding-Era documents. It equates all serious crimes with crimes for which the defendant was subject to capital punishment, although that was not the case in the Founding Era. The historical context in which the Second Amendment was adopted is manifestly insufficient to conclude that a restriction not actually present at the time-that all who had previously committed serious crimes were excluded from firearms rights-was implicitly read into its language.

242 See Claude G. Bowers, Jefferson and Hamilton: The Struggle for Democracy IN AMERICA 43-46 (referencing full repayment of debt purchased at discounts of $80 \%$ or more).

243913 F.3d 152, 158 (D.C. Cir. 2019) ("With this perspective, it is difficult to conclude that the public, in 1791, would have understood someone facing death and estate forfeiture to be within the scope of those entitled to possess arms.").

244 See supra notes 32-33, 62 and accompanying text. 
Contemporary courts, then, are not required by the Founding-Era precedent to exclude the "non-virtuous" from all firearms rights. The propriety of contemporary judicial reliance on a person not being "virtuous" as a basis to deprive him or her of firearms rights, then, depends on that being a valid approach generally, under contemporary constitutional norms.

The following Part turns to the contemporary judicial reliance on a person not being virtuous as curtailing some of his or her constitutional rights. As we shall see, Supreme Court precedent rejects that approach. Additionally, the almost insignificant number of contemporary cases that follow that approach use it to support odious outcomes.

\section{CONTEMPORARY CASES REFERENCING THE VIRTUOUS OUTSIDE THE CONTEXT OF THE SECOND AMENDMENT}

\section{A. Case Statistics}

To assess the extent to which modern courts have considered a person being not being "virtuous" in ascertaining the scope of his or her constitutional rights, the following Westlaw search of opinions was performed: adv: virtuous \& ("rational basis" or "intermediate scrutiny" or "strict scrutiny"). This revealed a total of 141 opinions. Our data set of opinions was reduced ${ }^{245}$ to 138 by omitting three issued before $1969 .{ }^{246}$

The number of opinions per year is depicted in the following figure, with the light gray bars showing opinions including the phrase "Second Amendment" tallied per year (identified as "2A"):

245 This search does not omit cases referencing "non-virtuous" instead of "virtuous." See Westlaw search: advanced: ("rational basis" "intermediate scrutiny" "strict scrutiny") \& non-virtuous \% virtuous) (May 22, 2020) (identifying two secondary sources but no cases).

246 The omitted cases are from 1949, 1920 and 1871. 


\section{Figure 1}



Of course, one could use other filters to identify cases that reference one being virtuous. One could search for cases including "virtue," which would involve many irrelevant cases including terms such as "by virtue of." Or, one could use different filters to identify those addressing constitutional issues. Indeed, this investigation involves sampling of opinions. As long as the filter is not biased-and there is no reason to suppose that it is-the analysis of the sampled results is designed to illuminate the general issue.

The annual number of opinions not referencing "Second Amendment" throughout the fifty-year period varies from zero to four. The first opinion referencing the Second Amendment occurs in 2006. Starting in about 2010, the typical number of opinions per year increases, with opinions referencing "Second Amendment" generally outnumbering the others.

An additional initial indication that reference to "virtuous" is used differently in cases involving the Second Amendment is illuminated by referencing a discrepancy in frequency with certain Westlaw KeyCite flags are associated with the opinions. The most adverse indicator, red, is associated with $11 \%$ of the opinions containing "Second Amendment," and $25 \%$ of the other opinions. ${ }^{247}$ That is, this signal is more than twice as

247 Westlaw describes a red KeyCite flag as indicating the opinion "is no longer good law for at least one of the points of law it contains." Thomson Reuters Westlaw, KeyCite on Thomson Reuters Westlaw (2016), https://scontent.westlaw.com/images/content/KeyCite $\% 20$ on\%20Westlaw.pdf. The yellow flag indicates the opinion "has some negative treatment." $I d$. 
common among opinions not containing "Second Amendment" than it is in opinions containing that phrase.

Figure 2

\begin{tabular}{|c|c|c|c|c|c|c|c|c|c|c|}
\hline \multirow[b]{3}{*}{ Cert. Pet. } & \multicolumn{4}{|c|}{ All Years } & \multicolumn{2}{|c|}{ Before 2006} & \multicolumn{4}{|c|}{2006 and after } \\
\hline & \multicolumn{2}{|c|}{ No $2 \mathrm{~A}$} & \multicolumn{2}{|c|}{$2 \mathrm{~A}$} & \multicolumn{2}{|c|}{ No $2 \mathrm{~A}$} & \multicolumn{2}{|c|}{ No $2 \mathrm{~A}$} & \multicolumn{2}{|c|}{$2 \mathrm{~A}$} \\
\hline & 0 & $0 \%$ & 1 & $2 \%$ & & & 0 & $0 \%$ & 1 & $2 \%$ \\
\hline None & 35 & $42 \%$ & 29 & $54 \%$ & 20 & $36 \%$ & 15 & $54 \%$ & 29 & $54 \%$ \\
\hline Red & 21 & $25 \%$ & 6 & $11 \%$ & 14 & $25 \%$ & 7 & $25 \%$ & 6 & $11 \%$ \\
\hline Yellow & 28 & $33 \%$ & 18 & $33 \%$ & 22 & $39 \%$ & 6 & $21 \%$ & 18 & $33 \%$ \\
\hline Total & 84 & & 54 & & 56 & & 28 & & 54 & \\
\hline
\end{tabular}

So, at this point, we have: Cases that reference the virtuous disproportionately involve the Second Amendment, and cases that reference the virtuous but don't involve the Second Amendment are more frequently dubious.

\section{B. Relevant Supreme Court Authority}

The raw statistics presented in Part VI.A suggest a qualitative difference in the extent to which courts rely on whether a person is "virtuous" in ascertaining the scope of constitutional rights, depending on whether the Second Amendment is at issue. However, a review of the analyses of the cases not implicating the Second Amendment, i.e., review of the opinion language, reveals the variation is more profound. The raw statistics above, before considering how reference to being "virtuous" is used in an opinion, overstate reliance on this principle in cases not involving the Second Amendment. The bulk of them reference the virtuous or non-virtuous in some inapposite context. So, actual reliance on this principle, as a basis to curtail an express right, is almost entirely absent from the sample outside the context of the Second Amendment.

As noted above, ${ }^{248}$ the contemporary justification for validating firearms prohibitions arising from any felony convictions, and exempting them from even as-applied challenge, relies on the notion that absence of virtue, a consequence of a conviction for a "serious" crime, can work a forfeiture of a civil right. The relevant Supreme Court authority in the sample, outside the context of the Second Amendment, however, expressly rejects that view. So it is not simply that reliance on a person not being virtuous is more frequently made in cases involving the Second Amendment. Rather, outside the Second Amendment context, the Supreme Court expressly rejects the view that these lower courts have resuscitated in the Second Amendment context.

248 See supra notes 67, 79-81, 94, 98 and accompanying text. 
The Supreme Court case referencing the issue-the constitutional consequences of not being "virtuous" - that is most prominently reliedupon by other courts since the middle of the last century is Hill v. Texas. ${ }^{249}$ Hill v. Texas explicitly rejects curtailment of constitutional rights by virtue of the fact that a person is not "virtuous."

The case involves a motion to quash an indictment for rape, on the basis that the selection of grand jurors was infected by racial discrimination. ${ }^{250}$ The Court holds that the State failed to rebut the claimant's prima facie case of racial discrimination in violation of the Equal Protection Clause, relying on raw statistics. ${ }^{251}$ The Court concludes the defendant might thereafter be indicted and tried, but only under procedures conforming to constitutional requirements. ${ }^{252}$

The litigation revealed substantial evidence of the defendant's having actually committed the crime. ${ }^{253}$ Yet the Court ends its opinion with the following language bearing on the relationship between being virtuous and benefitting from constitutional protection:

Nor is this Court at liberty to grant or withhold the benefits of equal protection, which the Constitution commands for all, merely as we may deem the defendant innocent or guilty. . . . Equal protection of the laws is something more than an abstract right. It is a command which the state must respect, the benefits of which every person may demand. Not the least merit of our constitutional system is that its safeguards extend to all-the least deserving as well as the most virtuous. ${ }^{254}$

249316 U.S. 400 (1942).

250 Id. at $400-01$.

251 Id. at 404 (referencing the "continuous omission of [blacks] from the grand jury lists for so long a period as sixteen years or more").

252 Id. at 406.

253 The petitioner was convicted of rape. Hill v. State, 157 S.W.2d 369, 370 (Tex. Crim. App. 1941), rev'd sub nom. Hill v. Texas, 316 U.S. 400 (1942). His identity was evidenced by: (i) a paper documenting his prison discharge being inside a pocket torn from the offender's coat during the criminal altercation; (ii) his confession to assault, but a denial of rape; and (iii) the identification by both the victim and a companion present at, and also victimized at, the scene. Hill v. State, 157 S.W.2d at 370-71. In addition, four passers-by saw the final moments of the violent encounter. Id. at 370-71.

The constitutional violation found by the Court, involving the manner in which the petitioner had been indicted, does not indict the decision-making process of the petit jury's finding the petitioner had committed the offense.

254316 U.S. at 406.

Of course, there is an ebb and flow over time in the norms as to what attributes give rise to being "virtuous." A concurring opinion in Richards v. Wisconsin, 520 U.S. 385, 392 n.4 (1997), cautions against relaxing constitutional restrictions on governmental action on the basis of changed social norms:

It is always somewhat dangerous to ground exceptions to constitutional protections in the social norms of a given historical moment. The purpose of the Fourth Amendment's requirement of reasonableness "is to preserve that degree of 
The Court's reference to a party not being virtuous is not dicta. Rather, it is part of the analysis yielding the holding.

Additionally, the court uses the term "virtuous" with a meaning analogous (or somewhat) analogous to the usage in the Founding Era. It appears related to performance of duties as a citizen-compliance with law-as opposed to an alternative, more modern, usage referencing lack of promiscuity.

Lastly, the court follows this approach in a circumstance that restrains punishment for egregious acts.

The principle was more recently referenced by the Supreme Court in a concurring opinion in First National Bank of Boston v. Bellotti, ${ }^{255}$ a case that follows a similar approach as to the consequences of being virtuous. In the case, the Court expressly disclaims the notion that a person's being virtuous increases his (in that case, its) free speech rights.

The case involves a state statute restricting the scope of corporate speech rights. In particular, the statute prevented banks and certain business corporations from making political contributions. ${ }^{256}$ The concurring opinion states the following as to the import of any allegation that media conglomerates would be more virtuous than other business enterprises:

In terms of Massachusetts' other concern, the interests of minority shareholders, I perceive no basis for saying that the managers and directors of the media conglomerates are more or less sensitive to the views and desires of minority shareholders than are corporate officers generally. Nor can it be said, even if relevant to First Amendment analysis-which it is not-that the former are more virtuous, wise, or restrained in the exercise of corporate power than are the latter. ${ }^{257}$

\section{Apt References to Virtuous Persons in Contemporary Lower-Court Jurisprudence Citing a Scrutiny Standard}

Introduction. Review of the lower-court authority identified in our search of opinions reveals the following pattern:

- Some lower-court authority relies on the principle expressed in Hill v. Texas in discussions finding Equal Protection violations-in

respect for the privacy of persons and the inviolability of their property that existed when the provision was adopted-even if a later, less virtuous age should become accustomed to considering all sorts of intrusion 'reasonable."

Id. (quoting Minnesota v. Dickerson, 508 U.S. 366, 380 (1993) (Scalia, J., concurring)).

255435 U.S. 765, 795 (1978) (Burger, C.J., concurring).

256435 U.S. at 793 (majority opinion).

257435 U.S. at 797 (Burger, C.J., concurring) (footnote omitted). 
favor of unwed mothers (as to educational opportunities), ${ }^{258}$ aliens (as to educational opportunities), ${ }^{259}$ and motor vehicle guests (as to claim limitation under guest statutes);260 and

- Other lower-court authority limits introduction of evidence of a crime victim's attributes, as implicitly casting a criminal defendant in a poor light, ultimately founded on principles of the Eighth Amendment and that "[t]he law exists to protect all persons equally."261

Of course, all this authority highlights that Second Amendment rights are treated adversely, in comparison with the treatment of other enumerated rights.

A reference to being non-virtuous as a basis for curtaining rights bleeds into a few contemporary cases through citation to noncontemporary cases that rely on that mode of analysis, in language or in a context that is contrary to contemporary norms. ${ }^{262}$ Excluding those cases, the entire scope of contemporary authority, not referencing the term "Second Amendment," relying on a person not being virtuous as a basis for curtailing rights, is apparently limited to the following three illustrations:

- authority upholding criminalization of sexual contact between persons of the same gender;263

258 See infra notes 270-Error! Bookmark not defined. and accompanying text.

259 See infra notes 274-278 and accompanying text.

260 See infra notes 279-284 and accompanying text.

261 State v. Williams, 550 A.2d 1172, 1203 (N.J. 1988). A number of contemporary cases from New Jersey examine whether the fact that a crime victim was virtuous can be introduced. Oliver v. Hendricks, No. CIV.A. 04-4219 (JAG), 2006 WL 1540823, at *1, *5-6 (D.N.J. May 31, 2006); State v. Muhammad, 678 A.2d 164, 179 (N.J. 1996); State v. Erazo, 594 A.2d 232, 258 (N.J. 1991) (Handler, J., concurring in part and dissenting in part); State v. Cooper, Nos. A-2011-12T1, A-2988-12T1, A-3099-12T, 2014 WL 11072007, at *16 (N.J. Super. Ct. App. Div. Sept. 4, 2015). Williams is not included in the sample because it does not include "rational basis," "strict scrutiny" or "intermediate scrutiny."

262 Mountain States Tel. \& Tel. Co. v. Pueblo of Santa Ana, 472 U.S. 237, 241 n.8 (1985) (quoting prior authority stating, the "pueblo Indians . . . are a peaceable, industrious, intelligent, honest, and virtuous people." (quoting United States v. Joseph, 94 U.S. 614, 616 (1876)); Barbara A. v. John G., 193 Cal. Rptr. 422 (Ct. App. 1983) (discussing the abolished cause of action for seduction as, "The old action for seduction required that the woman was '. . . chaste and virtuous at the time of the alleged seduction ...', and it was used primarily to protect young, inexperienced women who had succumbed to the sexual advances of older men." (quoting Briggs v. Stroud, 126 P.2d 409, 413 (Cal. Ct. App. 1942)); Roundtree v. United States, 581 A.2d 315, 335 n.17 (D.C. 1990) (Schwelb, J., concurring in part and dissenting in part) (quoting an earlier opinion as follows: "[W]ill you not more readily infer assent in the practiced Messalina, in loose attire, than in the reserved and virtuous Lucretia?" (quoting People v. Abbot, 19 Wend. 192, 195 (N.Y. Sup. Ct. 1838)); State v. Rundlett, 391 A.2d 815, $820 \&$ n.17 (Me. 1978), (including in a collection of cases that it describes as having "prior chastity was an element of the offense" of statutory rape, one statute requiring the victim be "[o]f previous chaste and virtuous character." (quoting 1895 Okla. Sess. Laws 104)).

263 See infra notes 285-295 and accompanying text. 
- criminalization of heterosexual, consensual oral sex;264 and

- ancillary judicial ruminations by Judge Easterbrook, in a concurring opinion, concerning treatment of prisoners. ${ }^{265}$

Lastly, a number of cases identified in the text-based opinion search that do not reference "Second Amendment" are inapposite to our inquiry. Those cases address being "virtuous," where the reference does not concern whether being virtuous influences the extent to which one benefits from a constitutional right.

In particular, a number of cases address defining the scope of those beliefs that are religious and, therefore, within the protection of the Religion Clauses.266 That authority addresses what is the protected conduct, rather than who benefits.

264 See infra notes 296-298 and accompanying text.

265 See infra notes 299-306 and accompanying text.

266 In Wisconsin v. Yoder, 406 U.S. 205 (1972), the Supreme Court addresses what is protected by the Religion Clauses. stating, "A way of life, however virtuous and admirable, may not be interposed as a barrier to reasonable state regulation of education if it is based on purely secular considerations . ..." Id. at 215. A large number of the cases collected in the text search of opinions quote this language in Yoder. E.g., Moore-King v. Cty. of Chesterfield, 708 F.3d 560, 571 (4th Cir. 2013) (quoting Yoder, 406 U.S. at 215), abrogated by Nat'l Inst. of Family \& Life Advocates v. Becerra, 138 S. Ct. 2361 (2018); Littlefield v. Forney Indep. Sch. Dist., 268 F.3d 275, 290 \& n.22 (5th Cir. 2001) (quoting Yoder), affirming Littlefield v. Forney Ind. Sch. Dist., 108 F. Supp. 2d 681, 699 (N.D. Tex. 2000) (quoting Yoder); Herndon v. Chapel Hill-Carrboro City Bd. of Educ., 89 F.3d 174, 178 (4th Cir. 1996) (quoting Yoder), aff'g Herndon v. Chapel Hill-Carrboro City Bd. of Educ., 899 F. Supp. 1443, 1451 (M.D.N.C. 1995) (quoting Yoder); Immediato v. Rye Neck Sch. Dist., 73 F.3d 454, 461 (2d Cir. 1996) (quoting Yoder); Middleton v. Pan, No. Cv 16-5224-svw (Agr), 2016 WL 11518596, at *7 (C.D. Cal. Dec. 15, 2016) (quoting Yoder), report and recommendation adopted, No. CV 16-5224-SVW (AGR), 2017 WL 10543984 (C.D. Cal. July 13, 2017); Whitlow v. California, 203 F. Supp. 3d 1079, 1086 n.3 (S.D. Cal. 2016) (quoting Yoder); Conner v. Tilton, No. C 07-4965 MMC (PR)b, 2009 WL 4642392, at *14 (N.D. Cal. Dec. 2, 2009) (quoting Koger v. Bryan, 523 F.3d 789, 797-98 (7th Cir. 2008) (quoting Yoder)), affd, 430 F. App'x 617 (9th Cir. 2011); Jensen v. Reeves, 45 F. Supp. 2d 1265, 1275 (D. Utah 1999) (quoting Yoder), aff'd, 3 F. App'x 905 (10th Cir. 2001); Shabazz v. Barnauskas, 600 F. Supp. 712, 724 (M.D. Fla. 1985) (quoting Yoder), aff'd, 790 F.2d 1536 (11th Cir. 1986); Brush \& Nib Studio, LC v. City of Phoenix, 448 P.3d 890, 919 (Ariz. 2019) (quoting Yoder); Catholic Charities of Sacramento, Inc. v. Superior Court, 85 P.3d 67, 92 (Cal. 2004); Warner v. City of Boca Raton, 887 So. 2d 1023, 1027 (Fla. 2004) (quoting Yoder); People v. DeJonge, 501 N.W.2d 127, 135 (Mich. 1993) (quoting Yoder); State v. Shaver, 294 N.W.2d 883, 891 (N.D. 1980) (quoting Yoder); Luken v. Brigano, 797 N.E.2d 1047, 1051 (Ohio Ct. App. 2003) (quoting Yoder); Larson v. Burmaster, 720 N.W.2d 134, 148 (Wisc. Ct. App. 2006) (quoting Yoder); Shannon \& Riordan v. Bd. of Zoning Appeals, 451 N.W.2d 479, 486 (Wisc. Ct. App. 1989). It was also quoted in a dissent in a case reversed on appeal. Nw. Indian Cemetery Protective Ass'n v. Peterson, 795 F.2d 688, 701 (9th Cir. 1986) (Beezer, J., dissenting in part), rev'd sub nom. Lyng v. Nw. Indian Cemetery Protective Ass'n, 485 U.S. 439 (1988).

Additionally, many cases paraphrase Yoder in terms referencing being "virtuous." Birkes v. Mills, No. 03:10-cv-00032-HU, 2011 WL 5117859, at *7 (D. Or. Sept. 28, 2011), report and recommendation adopted, No. 03:10-CV-32-HU, 2011 WL 5118787 (D. Or. Oct. $25,2011)$, vacated, Dec. 16, 2011, and report and recommendation adopted, No. 03:10-CV- 
A few cases reference the need for a virtuous citizenry in supporting the value of education, either through parenting or as provided by schools. ${ }^{267}$ That authority as well does not bear on our issue: Whether some class of persons, on account of not being virtuous, does not benefit from a constitutional right. Rather, that authority examines the extent to which the public at a whole has some right.

Let us exclude (i) cases that make reference to the virtuous or nonvirtuous only through reference to non-contemporary cases relying on that approach (an offensive character being a unifying theme);268 and (ii) the ruminations of Judge Easterbrook. That leaves us with only two reported cases in the last half-century, referencing at least one of three constitutional standards of scrutiny but not referencing the term "Second Amendment," in which a judge relies on persons not being virtuous as a basis for curtailing civil rights. Each uses "virtuous," not as is being used in the Second Amendment context (as was used in the Founding Era), but, rather, in respect of the extent and nature of sexual activity. And each is no longer good law. The remainder of this Part VI.C provides some details of the cases that have been classified as provided in this introduction to Part VI.B.

32-HU, 2012 WL 930243 (D. Or. Mar. 19, 2012); Monroe v. Commonwealth, Unemployment Comp. Bd. of Review, 535 A.2d 1222, 1225 (Pa. Commw. Ct. 1988) (stating, "And, secular beliefs however virtuous and admirable, of course, do not fall within the ambit of First Amendment protection.").

Cochran v. City of Atlanta, 289 F. Supp. 3d 1276 (N.D. Ga. 2017), examines a claim a governmental employee was fired for publishing a book titled, Who Told You That You Were Naked?: Overcoming the Stronghold of Condemnation, has as a "goal[" "to guide men to live faith-filled, virtuous lives." Id. at 1282. The court concludes, inter alia, it "not unreasonable" to conclude the book's publication would have made it difficult to recruit LGBT personnel, id. at 1290-91, in dismissing the plaintiff's free speech retaliation claim. Id. at 1288, 1291-92. The employee's position is also discussed in a prior proceeding. Cochran v. City of Atlanta, 150 F. Supp. 3d 1305, 1308-09 (N.D. Ga. 2015).

267 Perhaps most prominent would be a dissent by Justice Thomas in Brown v. Entertainment Merchants Ass'n., 564 U.S. 786 (2011). In that case, Justice Thomas dissents from a holding that the First Amendment invalidates "a state law that prohibits the direct sale or rental of certain video games to minors because the law 'abridg[es] the freedom of speech." Id. at 821 (alteration in original) (quoting U.S. ConsT. amend. I). In support of his view, he asserts, as to the late eighteenth and early nineteenth centuries:

[I]t was widely accepted that children needed close monitoring and carefully planned development. ... .

The Revolution only amplified these concerns. The Republic would require virtuous citizens, which necessitated proper training from childhood. . . .

Based on these views of childhood, the founding generation understood parents to have a right and duty to govern their children's growth. Id. at $827-28$.

Our search identified other cases involving access to education. Lake View Sch. Dist. No. 25 of Phillips Cty. v. Huckabee, 91 S.W.3d 472, 491 (Ark. 2002), supplemented, 189 S.W.3d 1 (Ark. 2004); Milliken v. Green, 212 N.W.2d 711, 718 n.6 (Mich. 1973) (Kavanagh \& Levin, JJ., concurring); Brigham v. State, 692 A.2d 384, 393 (Vt. 1997).

268 See supra note 262. 
Equal Protection Cases Following Hill v. Texas. Our search uncovered three opinions, excluding one reversed on appeal, ${ }^{269}$ that favorably rely on the above-quoted principles from Hill v. Texas. Perry v. Grenada Municipal Separate School District ${ }^{270}$ involves a challenge, under the Equal Protection Clause, to a "policy of the school board of denying admission to unwed mothers." 271 In the introductory paragraph beginning its Equal Protection analysis, the court concludes by quoting the last two sentences from Hill v. Texas quoted above. ${ }^{272}$

The court concludes the policy is unconstitutional. For our purposes, the relevance of the case is two-fold. First, the court, in relying on Hill, rejects the notion that not being virtuous results in forfeiture of constitutional rights. Second, it is not the core of the Founding Era conceptualization of a virtuous citizen $^{273}$ that gives rise to putative potential for classification as non-virtuous but, rather, sexual activity. Although the more modern references are not limited to sexual activity, they do seem to be concentrated in supporting views that are peculiar from the contemporary perspective.

In re Alien Children Education Litigation $^{274}$ provides a second illustration of a court quoting Hill v. Texas. The opinion notes:

At issue is a statute which prohibits the use of a state fund to educate persons who are not citizens of the United States or "legally admitted aliens." That statute by negative implication also permits local school officials to exclude undocumented children from the public schools. ${ }^{275}$

This court as well concludes an Equal Protection analysis, which holds the statute unconstitutional, ${ }^{276}$ with a paragraph including a quotation from a portion of Hill $v$. Texas quoted above. ${ }^{277}$

269 A fourth opinion quoting Hill, from an intermediate California appellate court, was reversed on appeal. People v. Guzman, 3 Cal. Rptr. 3d 339 (Ct. App. 2003), rev'd, 107 P.3d 860 (Cal. 2005). The intermediate appellate court holds unconstitutional, as a violation of Equal Protection, id. at 353, a statutory scheme addressing recidivism, providing better treatment for those on parole than those on probation. Because the case was reversed on appeal, it does not comfortably fit in the same class as other contemporary authority implementing the treatment of the non-virtuous referenced in Hill v. Texas.

270300 F. Supp. 748 (N.D. Miss. 1969).

271 Id. at $749-50$.

272 Id. at 750-51 (quoting Hill v. Texas, 316 U.S. at 406) (quoting the last two sentences quoted supra text accompanying note 254).

273 See supra notes 100-103 and accompanying text.

274501 F. Supp. 544 (S.D. Tex. 1980), aff'd unreported mem. (5th Cir. Feb. 23, 1981), aff'd sub nom. Plyler v. Doe, 457 U.S. 202 (1982).

$275 I d$ at 549 (footnote omitted) (citation omitted).

276 Id. at 584.

277 Id. at 583 (quoting Hill v. Texas, 316 U.S. at 406) (quoting the last two sentences quoted supra text accompanying note 254). 
It is somewhat difficult to contextualize the court's reference to those not virtuous. The court notes, "Section 21.031 penalizes children because of acts committed by their parents," 278 suggesting that insofar as there is some reference to persons not being virtuous, it would be attributed to the parents of the adversely affected children. In any case, the pertinent perspectives illuminated by this opinion are that reference to one not being virtuous is discredited in ascertaining the scope of constitutional rights.

Our third lower-court case in our data set relying on Hill v. Texas is McGeehan V. Bunch. ${ }^{279}$ McGeehan examines the constitutionality of a guest statute, which prevented recovery by non-paying guests against their drivers for mere negligence. ${ }^{280}$ The case addresses "whether or not [New Mexico's] guest statute by creating a distinction between paying and nonpaying automobile guests violates the equal protection clause of the federal and state constitutions."281

One justification for the statute that the court examines is to "promote hospitality, by excluding one who gratuitously provides a ride from suit based on ordinary negligence," 282 the principle being that "to sue one's host for negligence is the epitome of ingratitude." 283 The court rejects the notion that lack of virtue, in the form of ingratitude, forms a suitable consideration for elimination of compensation for ordinary negligence. The opinion adopts the analysis in a student comment, which states in part: "Moreover, it has been suggested that 'it is none of the state's business what kind of virtuous emotions the citizenry feels or fails to feel.' Indeed, it is questionable whether the protection against ingratitude is a permissible state interest."'284

In sum, these cases referencing being "virtuous" in ascertaining the scope of constitutional rights reject the notion that rights are diminished where one is not virtuous.

Modern Opinions Referencing the Non-Virtuous as Having Diminished Rights and the Reason to Reject That Authority. There are some contemporary, or almost-cotemporary, opinions that chart a course away from the referenced principle expressed in Hill v. Texas. The small collection of majority opinions at the core are decades old, and reflect

278 Id. at 572. The court goes on to quote another case to the following effect: "A more exacting scrutiny of the Texas law also appears warranted when consideration is given to the decisions of the Supreme Court refusing to penalize and stigmatize children who are not in a position to prevent the wrongful acts of their parents." Id. at 573 (quoting Doe v. Plyler, 458 F. Supp. at 582).

279540 P.2d 238 (N.M. 1975).

280 Id. at 309.

281 Id. at 239.

282 Id. at 311.

283 Id. at $311-12$.

284 Id. at 312 (quoting JoAnn Wierwille, Comment, Review of the Past, Preview of the Future: The Viability of Automobile Guest Statutes, 42 U. CIn. L. REV. 709, 719-20 (1973). 
governmental intrusion into private sexual conduct, odious by contemporary standards and rejected by current jurisprudence.

Criminalization of Currently Protected Sexual Conduct. Let us turn to the two almost-contemporary cases that appear directly to reject the Hill $v$. Texas principle, i.e., cases that are the intellectual companions of cases that deny Second Amendment rights to persons deemed non-virtuous. Our summary illuminates the odious intellectual company kept by opinions depriving the non-virtuous of the civil right to bear arms.

State v. Walsh, ${ }^{285}$ a 1986 case, holds that criminalization of "deviate sexual intercourse with another person of the same sex" 286 violates neither the Equal Protection provisions of the Federal Constitution ${ }^{287}$ nor the Missouri Constitution. ${ }^{288}$ The court notes that, earlier in the year, the Supreme Court held in Bowers V. Hardwick, 289 "[T]he United States Constitution does not confer upon consenting homosexuals a fundamental right to engage in sodomy." ${ }^{290}$ The Missouri Supreme Court continues, distinguishing 1980 Pennsylvania authority291 invalidating a statute prohibiting some intimate activity between unmarried persons:292

We decline to follow the Pennsylvania Supreme Court, because we believe, to borrow from Mr. Justice Black, "Whether the legislature takes for its textbook [John Stuart Mill, Thomas Aquinas or Lord Devlin] or some other is no concern of ours. *** [R] elief, if any be needed, lies not with us but with the [General Assembly]."

We believe further that punishing homosexual acts as a Class A misdemeanor . . . is rationally related to the State's constitutionally permissible objective of implementing and promoting the public morality. ${ }^{293}$

The Missouri opinion alters Justice Black's language, substituting different "textbooks." 294

285713 S.W.2d 508 (Mo. 1986).

286 Id. at 509 (quoting Mo. REv. STAT. § 566.090.1(3) (1978), repealed by H.B. 1698, 1236, 995, 1362, 1290, 93rd Gen. Assemb., 2d Reg. Sess. (Mo. 2006)).

287 Id. at 513.

288 Id. at 513.

289478 U.S. 186 (1986), overruled by Lawrence v. Texas, 539 U.S. 558 (2003).

290 Walsh, 713 S.W.2d at 511.

291 Commonwealth v. Bonadio, 415 A.2d 47 (Pa. 1980).

292 Bonadio, 415 A.2d at 94 n.1.

293713 S.W.2d at 512 (alterations in original) (footnotes omitted) (quoting Ferguson v. Skrupa, 372 U.S. 726, 732 (1963)) (citing Thomas AqUINAs, Summa TheOloGiCA, pt. I-II, question 96, art. 2; and PATrick Devlin, The Enforcement of Morals (1965)).

294 See Skrupa, 372 U.S. at 732 (referencing "Adam Smith, Herbert Spencer, Lord Keynes, or some other"). 
The opinion includes reference to the "virtuous" in a footnote quoting Thomas Aquinas. Insofar applicable to the circumstances the court had under its consideration, it would indicate the following: It appears the Missouri Supreme Court deferred to an apparent determination by the Missouri General Assembly that the prohibited activity was one "from which the virtuous abstain": "Now human law is framed for a number of human beings, the majority of whom are not perfect in virtue. Wherefore human laws do not forbid all vices, from which the virtuous abstain, but only the more grievous vices *** and chiefly those that are to the hurt of others $* * * . " 295$

In sum, the Missouri Supreme Court's alteration of Justice Black's language provides one of the two somewhat recent cases in our data set, not referencing "Second Amendment," referencing persons who putatively are not virtuous in denying them constitutional protection. It does so in validating criminalization of consensual homosexual sexual activity.

The second such case is the 2000 case State v. Smith. ${ }^{296}$ In that case, the Louisiana Supreme Court rejects the argument that either the Federal Constitution or the Louisiana Constitution invalidates the criminalization of heterosexual, consensual oral sex. The opinion announcing the disposition states, "[T]he defendant would have us announce . . . a constitutional right to engage in oral sex. This we are unwilling to do."297 The court, by happenstance, quotes the same language from Ferguson $v$. Skrupa that the Missouri Supreme Court quoted fourteen years earlier in State v. Walsh, similarly altering the quote from Justice Black with the same reference to work from Thomas Aquinas that Walsh substituted. ${ }^{298}$

Other Contemporary Authority: Easterbrook's Paean to the Era of Chain Gangs. The other contemporary case most on-point in referencing the status as non-virtuous in supporting restrictions on civil rights is a concurring opinion by Judge Easterbrook in David K. v. Lane. ${ }^{299}$ The case involves incarcerated prisoners' claims that failure to enforce state regulations restricting gang activities in prison violated their Equal Protection rights, as well as federal regulations. ${ }^{300}$

Easterbrook uses a concurring opinion in the case to provide ancillary observations on treatment in prison. Easterbrook's opinion is untethered to the doctrine of the causes of action asserted-one would not describe the opinion as expounding a deductive analysis of the relevant textual source of law. None of the following character strings appears in the body of

295 Id. (quoting AQUINAS, supra note 293, pt. I-II, question 96, art. 2).

296766 So. 2 d 501 (La. 2000).

297 Id. at 506.

298 See 766 So.2d at 511 (substituting "[John Stuart Mill, Thomas Acquinas or Lord Devlin]" for the texts referenced by Justice Black (footnotes omitted)).

299839 F.2d 1265, 1278-80 (7th Cir. 1988) (Easterbrook, J., concurring).

300839 F.2d at $1266-67$ (majority opinion). 
Easterbrook's opinion: "Equal Protection" or "14th Amendment" or "Fourteenth Amendment" or "Title VI" (the title on which a federal regulatory claim was founded) ${ }^{301}$ or "CFR" or "C.F.R." 302 Of these, only "Equal Protection" appears in even a footnote (and that only once, to identify the ultimate conclusion.) ${ }^{303}$ Rather, after stating, "[Y] ou can't be a lion tamer without a whip and chair," ${ }^{04}$ Easterbrook opts to denigrate the complainants as part of supporting rejection of a claim:

The "governed" in prison are not virtuous republican yeomen. The crowd milling around the mess hall at Pontiac has little in common with the crowd in the lobby of the Lyric Opera of Chicago on opening night; it wasn't good manners that got people invitations to a maximum-security prison. A legal system that both requires prison officials to suppress gangs and informs them that we shall transfer their wealth to the gangs if they act too firmly asks the impossible. ${ }^{305}$

These observations are preceded by an apparent paean to the era of chain gangs and the like:

To cope with gangs, prisons must be able to inflict real punishments-sanctions going beyond mere presence in a maximum-security prison, for inmates suffer confinement and indignity whether they belong to gangs or not.

Thirty years ago a prisoner who wore forbidden insignia or sassed a guard could find himself on a chain gang. No more. He might have been thrown in the "hole" or put on bread and water for a month. No more. That would violate the current understanding of the Cruel and Unusual Punishments Clause. He might have had parole put off until doomsday, but the reduction of parole decisionmaking to a largely mechanical process-and the impending demise of parole under determinate sentencing schemes-make this less of a threat.

301 See 839 F.2d at 1274 (majority opinion).

302 See 839 F.2d at 1278-80 (Easterbrook, J., concurring) (these character strings not identified in body text with the following Westlaw search: adv: CI("839 F.2d 1265") \& ("equal protection" or "14th amendment" or "fourteenth amendment" or cfr or "c.f.r." or "title vi”)).

303 See 839 F.2d at 1279 n.3 (Easterbrook, J., concurring) ("Unless that change would have improved the minority's treatment, however, there is no "discrimination" within the meaning of the Equal Protection Clause.").

304839 F.2d at 1280 (Easterbrook, J., concurring).

305839 F.2d at 1280 (Easterbrook, J., concurring). 
He might have been stripped of good time credits or put in punitive segregation. These options are open still, but they are less valuable for two reasons. ${ }^{306}$

Conclusion. The purpose of our investigation is to illuminate the intellectual company of those cases that deny Second Amendment rights to those deemed not "virtuous." In sum, the raw search statistics suggested that, as to the rights of the non-virtuous, there is merely a significant deviation in approach, as between cases referencing the term "Second Amendment" and those that do not. However, after reviewing the language of the opinions, it is clear that understates the variation between the two classes of cases-those referencing "Second Amendment" and those not.

Within the collected cases not referencing the Second Amendment, curtailing enumerated rights for those who are not virtuous is not the norm. And, in the rare modern cases where it was followed, the outcome is odious, revealing the misuse to which this approach has been put.

\section{CONCLUSION}

A number of aspects of treatment of felons' firearms rights appears to evidence a hostility to exercise of the civil right. The history of the statutory restriction reflects an abdication of the legislative duty to make a considered decision in adopting statutes that curtail express rights-first allocating that duty to the Executive Branch, then allocating it to the courts. A class of persons with prior felony convictions-one supposes generally more affluent—was excluded from the prohibition. ${ }^{307}$ But there is no indication that this class of individual is less likely to abuse criminally the retained firearms rights, as compared to others whose firearms rights are taken away permanently.

A principle underlying our contemporary schemes for assessing Equal Protection challenges is to allow invalidation of restrictions on express rights that are attributable to legislative hostility to their exercise. ${ }^{308}$ That appears to be the case at hand, subject to the compounding factor of a portfolio of exceptions not justified as promoting a suitable interest but,

306 Id. at 1278.

307 See supra notes 43-53 and accompanying text.

308 In discussing strict scrutiny, Peter Rubin notes:

[T] he inquiry into narrow tailoring-into the fit between classification and proffered goal-serves at least three distinct purposes. First, it ensures that the stated purpose was indeed the actual purpose behind the classification. A narrow tailoring inquiry can help to "smoke out" illegitimate purposes by demonstrating that the classification does not, in fact, serve the stated, legitimate purpose."

Peter J. Rubin, Reconnecting Doctrine and Purpose: A Comprehensive Approach to Strict Scrutiny After Adarand and Shaw, 149 U. PA. L. REV. 1, 14 (2000) (citing City of Richmond v. J.A. Croson Co., 488 U.S. 469, 493 (1989) (plurality opinion)). 
instead, providing special benefit to a class with no identifiable basis for entitlement.

In the absence of an identifiable interest that is being promoted by the wholesale elimination of nonviolent felons' firearms rights, contemporary courts rely on (i) an assessment of the general philosophy of persons in the Founding Era, and a theoretical analysis of the implications of those philosophical viewpoints ${ }^{309}$ and (ii) a selection of Founding-Era documents curated with a filter that predetermines a conclusion unsupported by review of an unfiltered sample. ${ }^{310}$ That leads contemporary courts to conclude that the Founders intended for there to be an implicit limit on the Second Amendment involving firearms restrictions of a type that simply did not exist in the Founding Era. ${ }^{311}$

As we have seen, in the Founding Era, there were processes for restricting firearms rights of persons who were out and about. But, in contrast to the contemporary statutory scheme, which courts often summarily validate, the Founding-Era restrictions provided for judicial tailoring, both as to the identity of persons subject to restrictions as well as to the duration of the restrictions. ${ }^{312}$ That is, the Founding-Era restrictions allowed courts to match the restrictions to meet the rational objectives-as opposed to the contemporary statutory scheme that makes no pretense of being designed to do that.

Were Congress to revise the felon firearms prohibition to be of limited duration, e.g., of five or perhaps ten years, it would be much more difficult for a court legitimately to find the limited ban to be qualitative different from the Founding-Era regime.

In modern constitutional jurisprudence, the view that one's express constitutional rights can be forfeited because one is "non-virtuous" is generally rejected outside the context of the Second Amendment. 313 And those modern cases that relied on this principle did so to validate noxious prohibitions on non-commercial, consensual sexual activity-between same-sex couples and heterosexual couples. ${ }^{314}$ The judicial opinions that rely on this construct to read into the Second Amendment a limit without a glimmer of textual support, and the authors of those opinions, ought to be known by-and be held to account for-the odious company that they keep.

\footnotetext{
309 See supra notes 66, 120-122 and accompanying text.

310 See supra Part V.D.

311 See supra Part V.E.

312 See supra Part V.E.

313 See supra Part VI.

314 See supra notes 285-298 and accompanying text.
} 